\title{
Putting the entrepreneur back into entrepreneurial ecosystems
}

\author{
Andrei Alexander Lux, Flávio Romero Macau and Kerry Ann Brown \\ School of Business and Law, Edith Cowan University, Perth, Australia
}

\begin{abstract}
Purpose - This paper extends entrepreneurial ecosystems theory by testing how aspects of the local business environment affect individual entrepreneurs' ability to translate their personal resources into firm performance.

Design/methodology/approach - Data were collected from 223 business owners across Australia. Moderation hypotheses were tested using multiple hierarchical regression and confirmed with the Preacher and Hayes (2004) bootstrapping method.

Findings - The results show that business owners' psychological capital, social capital and entrepreneurial education directly affect their individual firm performance. These positive relations are moderated by specific aspects of the business environment, such that they are stronger when the environment is more favorable.

Originality/value - This study puts individual business owners back into entrepreneurial ecosystems theory and explains how they can make the most of their personal resources, suggesting a complex interplay where one size does not fit all. Far-reaching practical implications for policymakers are discussed.
\end{abstract}

Keywords Entrepreneurship, Entrepreneurial ecosystem, Psychological capital, Social capital,

Entrepreneurial education, Human capital, Firm performance, Ecological systems theory

Paper type Research paper

Productive entrepreneurship is always a combination of self and circumstance (cf. Baumol, 1990). Yet questions remain about how these two aspects interact to influence firm performance and without evidence, such notions remain in the shadowy realm of conjecture. We shed light on this topic by testing for specific moderation effects between entrepreneurs' personal resources and their business environment. We argue that the direct effects of entrepreneurs' psychological capital, social capital and entrepreneurial education are moderated by key aspects of the broader context within which their businesses operate. Favorable business environments enable such entrepreneurs to better leverage their personal resources, which translates into improved firm performance.

Moore (1993) observed that businesses are embedded within a wider relational context of suppliers, customers and regulatory frameworks - subsequently introducing the notion of a business "ecosystem." Borrowing from biology, the ecosystem approach focuses on the interaction of key actors with their physical environment, rather than their individual attributes alone. Gladwell (2008) provides a poignant example of this perspective when suggesting that:

the tallest oak in the forest is the tallest not just because it grew from the hardiest acorn; it is the tallest also because no other trees blocked its sunlight, the soil around it was deep and rich, no rabbit chewed through its bark as a sapling, and no lumberjack cut it down before it matured. (pp. 19-20)

CAndrei Alexander Lux, Flávio Romero Macau and Kerry Ann Brown. Published by Emerald Publishing Limited. This article is published under the Creative Commons Attribution (CC BY 4.0) licence. Anyone may reproduce, distribute, translate and create derivative works of this article (for both commercial and non-commercial purposes), subject to full attribution to the original publication and authors. The full terms of this licence may be seen at http://creativecommons.org/licences/by/4.0/ legalcode

This work was supported in part by research funding from the Centre for Innovative Practice at Edith Cowan University.

Received 23 January 2020 Revised 1 April 2020 29 April 2020

Accepted 30 April 2020

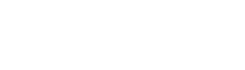

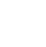

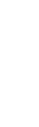


IJEBR

26,5

1012

Attributing this ecosystems viewpoint to the academic field of entrepreneurship has yielded the "entrepreneurial ecosystem" concept - a nascent framework for understanding the broader context within which entrepreneurship occurs: i.e. where individuals discover, evaluate and exploit opportunities for creating new goods and services (Shane and Venkataraman, 2000; Venkataraman, 1997). For an overview, see the recent Special Issue on entrepreneurial ecosystems in Small Business Economics (Acs et al., 2017).

Mason and Brown (2013) define entrepreneurial ecosystems (EEs) as consisting of interconnected entrepreneurial actors, organizations, institutions, processes and personal attributes, which "formally and informally coalesce to connect, mediate and govern the performance within the local entrepreneurial environment" (p. 5). Such an unwieldy, multilevel and multi-dimensional definition poses considerable clarity and measurement difficulties going forward. Instead, this paper builds on the work of Stam (2015) who defines EEs succinctly as a "set of inter-dependent actors and factors coordinated in such a way that they enable productive entrepreneurship" (p. 1,765). However, a workable definition cannot overlook that EEs operate within a geographic region (cf. Spilling, 1996) and that the elements of an EE are inter-related, since they can function separately, rather than interdependent. Furthermore, stipulating that various EE components are coordinated to enable entrepreneurship suggests a top-down approach to EE development and excludes organic cluster formation (see Feldman et al., 2005). Therefore, this paper augments Stam's (2015) original phrasing to define entrepreneurial ecosystems as: a set of inter-related actors and components, within a geographic region, that enable productive entrepreneurship.

Effectively transitioning from the traditional managed economy toward a modern entrepreneurial economy is an integral step toward securing the sustained prosperity of developed nations (Audretsch, 2009). The economic success of an EE is a function of individual firms' performance. Therefore, policymakers need clear guidance about how the various components of an $\mathrm{EE}$ affect individual firm performance so that they can deploy strategic resources to improve on areas of want and propel regions into higher levels of economic prosperity (Hechavarria and Ingram, 2014). However, the field of EE research is still in the early stages of development (Spigel, 2017) with limited empirical evidence to support causal relationships (for a critique, see Stam, 2015). The present study advances work on EEs by testing a set of hypotheses that model the effects of business context on perceived relative firm performance (hereafter “firm performance," see Delaney and Huselid, 1996).

This paper applies Ecological Systems Theory (Bronfenbrenner, 1979) to argue that the perceived favorability of the business environment will either enable or inhibit productive entrepreneurship. Much like human development, firms will grow on their own as a function of their individual assets and capabilities and the wider business environment within which they operate will also either contribute to their development, or hamper it. This paper first tests three factors' direct effects on firm performance: the business owners' psychological capital, their social capital, and entrepreneurial education. Having established these direct relationships, the paper then tests the extent to which the perceived favorability of specific aspects of the business environment moderates these effects on firm performance. The results begin to answer Roundy and Fayard (2019) by identifying some of the specific mechanisms and interactions between entrepreneurial ecosystem components and actors.

\section{Hypothesis development \\ Personal vesources}

The dominant trend in entrepreneurship research has been to focus on individual characteristics as predictors of success: e.g. personality traits (Nga and Shamuganathan, 2010), cognitive style (Cools and Van den Broeck, 2007), resources and capabilities (Kor et al., 2007), entrepreneurial education (Matlay, 2008), and demographics such as age or gender 
(Walker and Webster, 2007). Beyond traditional economic capital, the three main personal resources are human capital ("what you know"), social capital ("who you know") and psychological capital ("who you are") (Luthans et al., 2004). Within the present context, human capital is best captured as entrepreneurial education (for a meta-analysis, see Martin et al., 2013). Hence, this paper models respondents' psychological capital, social capital and entrepreneurial education as predictors of their firm performance.

Business owners' psychological capital, social capital and entrepreneurial education are not an exhaustive list of firm performance antecedents. Relevant firm-level frameworks and constructs exist in the competitive advantage literature, for example: the resource-based view of the firm and its focus on internal resources that are valuable, rare, non-imitable and nonsubstitutable (Barney, 1991; Peteraf, 1993); and dynamic capabilities, where firms reconfigure or integrate internal competences to cope with external changes (Teece et al., 1997). However, this paper focuses on individual level resources to reintegrate entrepreneurs into EEs theory, and the examination of firm-level interactions is outside the scope of the present work. The following sections, therefore, provide an overview of psychological capital, social capital and entrepreneurial education as business owners' individual level resources and explain how they directly affect firm performance.

Psychological capital. The concept of psychological capital represents a positive mental state that is characterized by increased hope, optimism, self-efficacy and resilience (Luthans et al., 2007; Luthans et al., 2007). Psychological resource theory (Hobfoll, 2002) explains that psychological capital is a mental resource that lends individuals the capacity to apply themselves to a task and overcome the challenges that may arise. In contrast to earlier works that proffer dispositional treatments of these sub-dimensions (e.g. Scheier and Carver, 1985; Sherer et al., 1982), the psychological capital literature conceives of them as states individuals can therefore increase their psychological capital through personal and professional developmental interventions (Luthans et al., 2006; Luthans et al., 2008). In business contexts, psychological capital improves performance (Luthans et al., 2007) and reduces stress (Avey et al., 2009).

Entrepreneurship is a psychologically challenging endeavor and new business owners are beset with numerous demands (Miller and Le Breton-Miller, 2017). Meeting these demands requires entrepreneurs to deploy mental resources to discover, evaluate and exploit business opportunities while also buffering the negative impact of setbacks and hardship. Business owners with strong psychological capital may draw on this personal resource to pursue productive entrepreneurship more successfully. Hence, empirical studies of entrepreneurs' psychological capital report positive effects on new venture performance (Envick, 2005; Hmieleski and Carr, 2008; Hmieleski et al., 2015). Parallel streams of research likewise identify positive relations between the constituent components of psychological capital and entrepreneurial success: for example, self-efficacy and optimism (for a meta-analysis, see Rauch and Frese, 2007). Therefore, according to psychological resource theory, entrepreneurs' psychological capital is a personal resource that they can draw on to improve their firm performance.

H1. Business owners' psychological capital positively affects their firm performance.

Social capital. New venture creation involves an idiosyncratic set of activities that includes the identification of business opportunities, the development and mobilization of resources (Hoang and Yi, 2015). Entrepreneurs are entrenched in a social context that both facilitates and constrains their ability to perform these activities (Leyden et al., 2014; Smith et al., 2017). Social capital theory (Lin, 2002) suggests that goodwill and resources arise from this network of relationships with colleagues, friends, family and other business people (Smith et al., 2017). Hence, Wouter Stam et al. (2014) define social capital as the "resources embedded in entrepreneurs' personal networks" (p. 152). Well-connected entrepreneurs have privileged 
IJEBR

26,5

1014 access to valuable resources (De Carolis and Saparito, 2006) and strong social capital is therefore essential for the success of new business ventures (Bauernschuster et al., 2010; Yoon et al., 2015).

A number of specific resources arise from social capital (for a review, see Hoang and Yi, 2015), including access to physical and financial resources (Stam et al., 2014; Yoon et al., 2015), information (De Carolis and Saparito, 2006; Tian et al., 2017; Liu and Lee, 2015), legitimacy (Smith et al., 2017; Hoang and Yi, 2015) and emotional support (Kim and Kang, 2014; Leyden et al., 2014). For example, individuals who are connected with key industry players or professional service associations may be informed about emerging technology, business opportunities, available talent or market conditions before they become public knowledge (De Carolis and Saparito, 2006; Liu and Lee, 2015). Entrepreneurs may also leverage their social capital to build legitimacy as a way of mitigating perceived risk by obtaining endorsement from well-regarded organizations or individuals within the network (Smith et al., 2017). Given the relational nature of EEs (Spigel, 2017), applying social capital theory therefore suggests that business owners are able to draw on various advantages from the resources embedded in their social network to improve the overall performance of their firm.

H2. Business owners' social capital positively affects their firm performance.

The quality and nature of social network interactions affect the resource outcomes (Hoang and Antoncic, 2003). Strong network ties generate norms of reciprocity and social support that facilitate collaboration among network members (Kim and Kang, 2014; Poon et al., 2012). Such close and frequent interactions enable tacit knowledge transfer and trusted resource exchange (Rodrigo-Alarcón et al., 2017; Uzzi, 1997; Zhao et al., 2011). On the other hand, diverse networks facilitate the timely location of needed resources (Batjargal, 2003) and link entrepreneurs to more distant social networks that provide access to novel information (Granovetter, 1973; McPherson et al., 2001). Therefore, entrepreneurs' social capital is determined by both the diversity and strength of their social network.

Entrepreneurial education. The notion that entrepreneurial education generates productive entrepreneurial activity is built upon human capital theory (for meta-analyses, see Bae et al., 2014; Martin et al., 2013). Human capital embodies the skills, experience and knowledge acquired through formal schooling or on-the-job training and mentoring (Tan, 2014). According to neoclassical human capital theory, education increases the productivity and earnings of individuals (Sweetland, 1996). Human capital is therefore consistently associated with increased firm performance (Crook et al., 2011) and successful entrepreneurship (Marvel et al., 2016). Entrepreneurial education encourages knowledge transfer and the development of reasoning and problem-solving skills, which promote motivational and cognitive outcomes that generate successful business start-ups (Gielnik et al., 2017). Therefore, human capital theory suggests that entrepreneurial education is an important personal resource of business owners that directly relates to their firm performance.

H3. Business owners' entrepreneurial education positively affects their firm performance.

\section{Ecological systems theory}

Bronfenbrenner (1979) introduced ecological systems theory (EST) to explain how contextual factors across various levels impact on human development. The theory evolved through three main phases: (1) examining the direct effects of context on development; (2) focusing on the context-individual interactions; and (3) understanding proximal processes, the interactions between contextual systems (for a review, see Tudge et al., 2009). According to the second phase version of EST, positive development is a function of the personal 
characteristics of the individual and the impact of their environment (Bronfenbrenner, 1989). For example, individuals who are possessed of desirable personality traits, assets and capabilities are more likely to be successful. If those individuals are also embedded within a favorable context that supports and encourages their endeavors, they are likely to be more successful than if their environment is somehow deficient and frustrates their efforts.

EST positions an individual within five nested systems: (1) the microsystem, which includes the institutions or groups with which the individual has direct and regular contact; (2) the mesosystem, comprised of the connection points between distinct microsystems; (3) the exosystem, made up of the broader social structures with which the focal individual has no direct interaction; (4) the macrosystem, which is the highest level of context and includes the economy, government and culture; and (5) the chronosystem, which addresses how the pattern of effects changes over the course of time (Neal and Neal, 2013). A core tenet of EST is that development cannot be wholly understood by only examining the focal individual, but must be framed within the wider context within which they operate. Because individual actors both affect and are affected by their environment, EST suggests that development emerges from the interaction of individuals and their context (Rosa and Tudge, 2013).

Since its inception, EST has been applied to a variety of research fields, including family studies (Meirong Liu, 2015), disaster recovery (Boon et al., 2012), economic development (Pocock et al., 2012) and entrepreneurship (Kline et al., 2013; Obschonka and Silbereisen, 2012). The original focus on human development can be transposed to analogous entities, such as the growth and performance of individual firms. For example, Rauch and Frese (2012) conclude that it is the interaction between entrepreneurs and their business environment that "predicts behavior better than any one of these factors alone" (p. 58). This paper therefore applies EST to explain how the relations between individual business owners and the microsystems of their firms are affected by the macrosystem of the business environment.

\section{Contextual factors as moderators of firm performance}

Entrepreneurs' personal resources and capabilities directly affect their firms' performance (Kor et al., 2007), which is consistent with the dominant streams of extant research. The present study proposes that business owners' psychological capital, social capital and entrepreneurial education in particular, positively affect firm performance. However, eschewing the context within which entrepreneurship takes place omits crucial elements from the equation (Suresh and Ramraj, 2012). Indeed, central questions for strategy-making involve the ecosystem where enterprises operate and their networks with other actors (Johanson and Vahlne, 2011). More recent works (e.g. Feld, 2012; Motoyama and Knowlton, 2017; Spigel, 2017) recognize this limitation and reconceptualize entrepreneurship as a phenomenon that exists within a community of independent actors (Stam, 2015) and interrelated components (cf. the seminal work of Van de Ven, 1993).

Applying ecological systems theory (Bronfenbrenner, 1989) suggests that the direct effects of business owners' psychological capital, social capital and entrepreneurial education are moderated by aspects of the broader context within which their businesses operate. Favorable business environments enable such entrepreneurs to better leverage their personal resources, which translates into improved firm performance. Whereas unfavorable conditions make it more difficult for business owners to apply their personal resources to achieve firm performance. Entrepreneurial ecosystems are inherently relational (Spigel, 2017), and hence it is the interaction between business owners and their environment that enables productive entrepreneurship to take place: neither favorable business conditions, nor well-equipped individuals, can generate sustained firm performance on their own.

Subjective entrepreneurial theory (Mahoney and Michael, 2005) explains that productive entrepreneurship is an inherently stochastic and subjective process, rather than a rational 


\section{IJEBR}

26,5

\section{6}

Figure 1.

Theoretical framework

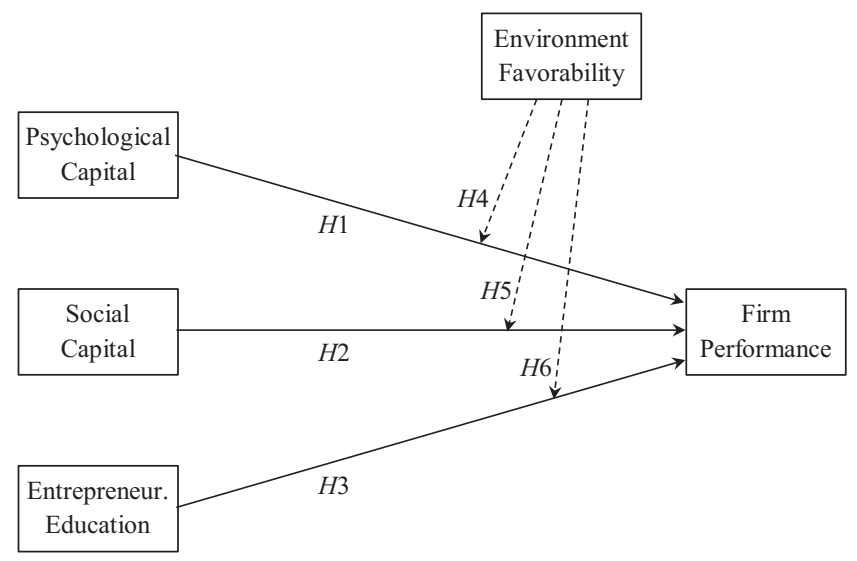

economic exploitation of means and opportunity. As decision-makers, business owners have bounded rationality (Simon, 1979) and act within a context of irreducible uncertainty (Kor et al., 2007). As such, individual actors' perceptions of the economic environment are a better predictor of their behavior than the objective reality (Bisgaard, 2015). Therefore, business owners' perceptions about the favorability of the local business environment positively moderate the relations between their personal resources and firm performance - that is, favorable business conditions enable productive entrepreneurship, rather than generate it.

H4. Business owners' perceptions of local business environment favorability positively moderate the relation between their psychological capital and firm performance.

H5. Business owners' perceptions of local business environment favorability positively moderate the relation between their social capital and firm performance.

H6. Business owners' perceptions of local business environment favorability positively moderate the relation between their entrepreneurial education and firm performance.

See Figure 1 for a path model diagram of the proposed theoretical framework. The following section discusses which specific aspects of the business environment affect entrepreneurial outcomes.

\section{Entrepreneurial ecosystem components}

The present work follows Spigel (2017) in principle to include eight components of an entrepreneurial ecosystem: government policy, access to capital, access to labor, access to professional services, physical infrastructure, university engagement, local attitudes toward entrepreneurship and access to mentors. Although Spigel (2017) also includes open markets and a history of entrepreneurship, these eight aspects are supported in a majority of the work on entrepreneurial ecosystems (Cohen, 2006; Feld, 2012; Global Entrepreneurship Monitor, 2017; Isenberg, 2011; Neck et al., 2004; Suresh and Ramraj, 2012; World Economic Forum, 2013). The following sections discuss each aspect in depth and explain the interactions with productive entrepreneurship.

Government policy. Governments influence contexts within which individuals choose whether or not to act (Autio et al., 2014), setting policies that either support or hinder entrepreneurs in a number of ways. To encourage productive entrepreneurship, governments should provide cost advantages such as reduced taxes (Mack and Mayer, 2016; Neck et al., 
2004), investment of public venture funds (Autio et al., 2014; Spigel, 2017) and other financial incentives (Stam, 2015); be less obtrusive, by reducing regulatory hurdles (Mack and Mayer, 2016), legal barriers (Spigel, 2017) and bureaucratic red tape for permits and licenses (Cohen, 2006; Neck et al., 2004; Spigel, 2017); legislate for intellectual property protection, entry regulations and competition, compelling firms to innovate when market forces are insufficient (Autio et al., 2014; Cohen, 2006).

Regional governments may also partner with organizations to take an active role in firm attraction and retention (Cohen, 2006; Mack and Mayer, 2016) by running incubation facilities (Spigel, 2017; Suresh and Ramraj, 2012); and deploy marketing campaigns to boost visibility (Mack and Mayer, 2016), by promoting awards (Autio et al., 2014), business competitions (Suresh and Ramraj, 2012) and networking events (Spigel, 2017). Successful governments cultivate a favorable climate to new business (Mack and Mayer, 2016), fostering networks of entrepreneurs and industry experts (Cohen, 2006; Spigel, 2017), influencing academic research activities (Auerswald and Dani, 2017; Autio et al., 2014) and working with universities to train skilled workers and future entrepreneurs (Spigel, 2017). Therefore, the favorability of government policy affects the performance of individual firms.

Access to capital. Capital is a fundamental component of an EE, available from financial institutions such as banks (Cohen, 2006; Suresh and Ramraj, 2012), private equity (Stam, 2015) and real-estate funds (Mack and Mayer, 2016). Well-developed financial markets must be available, visible and accessible to potential entrepreneurs at competitive rates to enable productive entrepreneurship (Kshetri, 2014; Spigel, 2017). Innovative entrepreneurship requires venture capitalists and angel investors who are risk-oriented and knowledgeable of the intricacies associated with investment in start-ups (Auerswald and Dani, 2017; Cohen, 2006; Mack and Mayer, 2016; Neck et al., 2004; Stam, 2015). Local small investors who are deeply connected with family, friends, their community or other social network actors may also play a part in financing new venture creation (Spigel, 2017; Stam, 2015; Suresh and Ramraj, 2012). Additional sources of financial capital may include suppliers, clients and even competitors through acquisition (Spigel, 2017). Governments also often offer special programs for SMEs in need of financial support (Suresh and Ramraj, 2012) and entrepreneurs' access to these various sources of capital influences the performance of their business ventures.

Access to labor/talent. A certain density of accessible skilled labor is necessary for the success of new ventures (Auerswald and Dani, 2017; Neck et al., 2004; Spigel, 2017; Stam, 2015). These heterogeneous talented professionals must have expertise that is well adapted to the specific demands of working at small firms (Cohen, 2006). Relevant qualifications and experience may include technical, managerial, product/market knowledge and connection with supplier/customer networks (Neck et al., 2004). Certain skills or attitudes likewise affect how amenable workers are to the typical chaotic start-up environment: for example, risk tolerance and uncertainty avoidance (Spigel, 2017). Workers can gain such capabilities from entrepreneurial courses at tertiary institutions (Björklund and Krueger, 2016), government training programs (Autio et al., 2014; Stam, 2015), prior work in incubators and start-ups (Neck et al., 2004) or from on-the-job training with previous employers (Mack and Mayer, 2016). These professionals are not necessarily already available in the area and may be attracted by the reputation of the region (Cohen, 2006; Neck et al., 2004; Spigel, 2017), sometimes traveling great distances as immigrant workers (Kshetri, 2014; Stam, 2015; World Economic Forum, 2013). Individual firm performance is thereby affected by regional access to relevant labor and talent pools.

Professional services. New firms need access to additional capabilities in the market that are peripheral to their core business model, that is the ability to hire integrated, effective and cost-efficient support services (Stam, 2015). Pertinent professional services include tax, legal, real-estate, insurance, consultant, accountant and other advisors (Cohen, 2006; Neck et al., 
IJEBR

26,5

1018
2004). These professionals should be acquainted to the peculiar challenges facing SMEs, especially start-ups, such as equity-for-service arrangements (Spigel, 2017). The availability of accessible and relevant professional services can influence both the start-up decision and ongoing success of entrepreneurial ventures. New business owner-operators must navigate this myriad of professional bureaucracies, which each require separate tertiary degrees to fathom. Entrepreneurs must therefore be confident in their ability to outsource these various tasks to local professional service providers in order to be successful.

Physical infrastructure. The physical infrastructure within an EE includes tangible public assets and facilities, such as serviceable roads/bridges, airports/rail and transport lines, retail/office/factory space, a clean water supply network, stable high-voltage electricity, highbandwidth telecommunication, waste disposal, public housing and mass transit (Mack and Mayer, 2016; Neck et al., 2004; Spigel, 2017; Stam, 2015; World Economic Forum, 2013). To further support the development of entrepreneurial ventures, aspects of the local physical infrastructure may be subsidized for SMEs (Cohen, 2006). Whether or not such physical infrastructure is available influences entrepreneurs' start-up decision, informs their location choice and ultimately either enables of inhibits productive entrepreneurship in that region.

University engagement. Extant treatments include university engagement nearunanimously as a fundamental component of an entrepreneurial ecosystem. The renowned "Triple Helix" framework serves as the first conceptual model of EEs by combining industry, government and university - according the latter a crucial role as instigators of innovation (Etzkowitz and Leydesdorff, 2000). The long-term viability of a socioeconomic system is wholly dependent on its ability to evolve by generating and embracing innovative advances (Dubina et al., 2017). Developing university engagement is therefore paramount to delivering said innovative economic climate and consequently, the sustainable economic growth of an EE. Consequently, studies of successful EEs report that university engagement performs an important role in enabling innovative new business venture creation (cf. Mason and Brown, 2013; Spigel, 2017; World Economic Forum, 2013). As such, economic regions that routinely engage with universities enable business owners to better leverage their personal resources and improve firm performance.

Local attitudes. Regional cultural perceptions of entrepreneurship exist at the intersection of individuals and their business community. Saxenian (1994) compares Silicon Valley with Boston, Massachusetts, to illustrate the pivotal role that local cultural attitudes play in the establishment of a successful $\mathrm{EE}$ - the differences in this example resulted in a marked divergence of regional economic development. Local cultural beliefs polarize perceptions of entrepreneurial activity, portraying it either as a viable career path or as a last resort, affecting the rate of new venture emergence (Kibler et al., 2014). Policymakers, however, still tend to import best practices from successful EEs, paying no heed to the cultural elements at play in the host (or home) location (Harrison and Leitch, 2010), which significantly contribute to, or inhibit, entrepreneurial activity. Indeed, Neck et al. (2004) report that a supportive regional culture was the single most beneficial component for EE development and prosperity. System-based approaches to entrepreneurship likewise highlight the centrality of local cultural elements during entrepreneurial framework adoption (see Acs et al., 2014; Sternberg, 2007). Hence, the local attitudes toward entrepreneurial activity, networks and mentorship play a key role in enabling productive entrepreneurship (Mack and Mayer, 2016).

Access to mentors. Practitioners (Feld, 2012; Isenberg, 2011) and scholars (Spigel, 2017) alike uphold the value of new entrepreneurs having ready access to local business mentors. This component is distinct from individual entrepreneurs' social capital, which captures the resources that they can leverage from their personal networks (Stam et al., 2014). In contrast to social capital, which is an individual or firm level construct, the availability of local business mentors is an ecosystem level phenomenon, concerned with whether or not - and to what extent - experienced and willing business mentors exist within the local business 
environment and are accessible to local entrepreneurs. When business mentors are available within an EE, new entrepreneurs can then establish high value mentorship relationships. Such arrangements are typically characterized by tacit knowledge transfer (De Carolis and Saparito, 2006) and thus enable business owners to more effectively leverage their personal resources to improve firm performance.

\section{Method}

Sample

An online survey was distributed to a sample of business owners across Australia. An Australian research company, PureProfile, was engaged to contact their panel members. Such a recruitment strategy is common in the organizational literature (e.g. Lux et al., 2019; Teo et al., 2016). The selection criteria specified that suitable participants must be of working age (15-64 years old), living in Australia and own an Australian-based business. A total of 1,680 panel members were contacted by Pure Profile and those who did not meet the selection criteria were excluded (73 did not live in Australia; 1,360 did not own a business; and a further 24 did not finish the survey). In total, 223 usable surveys were returned with complete data. The response rate was $13.3 \%$ and is comparable to the $16.8 \%$ incidence of business ownership in the working-age population of Australia, based on 2.3M businesses (Australian Small Business and Family Enterprise Ombudsman, 2019) and a working-age population of 13.7M (Australian Bureau of Statistics, 2020). Data were collected over 10 consecutive days and no substantive differences were observed between the early and late responders across all study variables, which supports the representativeness of the sample (Dalecki et al., 1993).

Respondent ages ranged from 18 to 64 years old (mean $=39.3, \mathrm{SD}=11.6)$ and the majority were between 25 and $34(33.1 \%)$ and 35-44 $(24.5 \%)$ years old. There were 146 female participants $(65.5 \%)$ and 75 male participants (33.6\%). Most respondents had pursued some form of education beyond the secondary school level $(81.2 \%)$, with the majority attaining bachelor's degrees $(44.8 \%)$ as their highest qualification. Participants were predominantly first-generation business owners $(79.8 \%$ ), with only $16.1 \%$ second generation, $4.0 \%$ third generation and none beyond that. Respondents' businesses were typically new ventures with $49.3 \%$ operating for three years or less and another $29.0 \%$ between 4 and 10 years. Most of the businesses were small, employing between 1 and $3(67.3 \%)$ or $4-10(19.7 \%)$ full-time staff. A broad range of industries were represented in the sample, with the largest portion engaged in professional services $(29.6 \%)$, followed by retail $(18.4 \%)$ and trade services $(10.8 \%)$. The respondents' demographic profile (age, gender, education and parents' business ownership) and firm statistics (age, size and industry) are sufficiently representative of business ownership across Australia to enable hypothesis testing (cf. Australian Small Business and Family Enterprise Ombudsman, 2019).

\section{Measures}

Psychological capital. Psychological capital is operationalized as a latent second-order construct comprised of four dimensions: hope, optimism, self-efficacy and resilience (Luthans et al., 2007). The present study used four validated instruments: an eight-item hope scale (Snyder et al., 1991), a six-item optimism scale (Scheier et al., 1994), an eight-item self-efficacy scale (Chen et al., 2001) and a six-item scale of resilience (Smith et al., 2008). All four of the individual instruments demonstrated reliability (hope $\alpha=0.90$, optimism $\alpha=0.71$, selfefficacy $\alpha=0.92$ and resilience $\alpha=0.80$ ) with Cronbach's alphas above the recommended 0.70 threshold (Nunnally, 1978). Respondents' psychological capital was calculated as the average of these four scales and the resulting 28-item composite instrument showed strong reliability $(\alpha=0.95)$.

\section{Entrepreneurial}

ecosystems 
IJEBR

26,5

1020

Social capital. Respondents' social capital was measured by capturing both the diversity and strength of their social network. Participants were provided with a list of nine different people whom they might approach when in need of business advice or support: for example "a relative," "a lawyer," "another entrepreneur," "a government agency," and asked how frequently they contact each one in this capacity, if at all. The response options ranged from "1 = never contact" to " 7 = extensively contact." Following Manolova et al. (2006), participants' network diversity was calculated by counting how many different categories were rated above "never contact." Following Wouter Stam and Elfring (2008), network strength was captured by the average frequency of contact across all of the categories rated above "never contact." Social capital was then calculated as the average of respondents' network diversity and network strength scores.

Entrepreneurial education. This study followed Maresch et al. (2016) to measure entrepreneurial education by asking participants how many courses related to entrepreneurship that they had previously completed. Response options included "none," "1-3 courses," "4-6 courses," and " 7 or more." Note that traditional reliability analysis, such as estimating Cronbach's coefficient alpha, is both impossible and unnecessary when unambiguous variables are directly observed in this manner (Wanous and Reichers, 1996).

Environment favorability. Respondents were first directed to consider the local business environment where their company primarily operates and then asked to rate how favorable each of the following conditions are to business ventures such as their own. Eight categories captured participants' perceptions about each of the distinct aspects of the local business environment, including: (1) government policy and regulations; (2) access to financial capital; (3) university engagement; (4) access to labor or talent; (5) access to professional services; (6) access to physical infrastructure; (7) availability of local business mentors; and (8) local attitudes toward entrepreneurship. Participant responses were recorded on a six-point Likert type scale, ranging from " 1 = very unfavorable" to " 6 = very favorable."

Firm performance. Numerous objective and financial measures exist that capture firm performance, including revenue, inventory turnover, return on equity, profit margin, sales growth, liquidity ratio, new patents and stock prices. However, most entrepreneurial ventures are SMEs that are not required to report financial data, and business owners are typically reluctant to volunteer it for research purposes. Participants' firm performance was therefore measured using a seven-item scale adapted from Delaney and Huselid (1996) which captures perceived relative firm performance along seven criteria that mirror the common indicators. Respondents were asked to rate their firm's relative performance over the last three years as compared to other local companies that do similar kinds of work across the following categories: (1) quality of products, services or programs; (2) development of new products, services or programs; (3) satisfaction of customers or clients; (4) marketing penetration; (5) growth in sales; (6) profitability; and (7) market share. Response options ranged from " $1=$ much worse" to " $6=$ much better" and the resulting scale demonstrated strong reliability $(\alpha=91)$. Such perceptual measures of relative firm performance are common in organizational research (e.g. Lau and Ngo, 2004; Youndt et al., 1996) and correlate positively with objective measures (Tomaskovic-Devey et al., 1994).

Social desirability. People have a general tendency to alter their responses to self-reported surveys in order to present a more favorable self-image; the phenomenon is known as social desirability bias and is a prevalent threat to research validity (King and Bruner, 2000). The process typically involves either overstating positive outcomes or understating negative outcomes and can significantly alter research results if not controlled during analysis (Van de Mortel, 2008). Respondents' social desirability was measured using the 13 -item short form of the original Marlowe-Crowne instrument developed by Reynolds (1982), which demonstrated good reliability $(\alpha=0.83)$. 
Control variables. In addition to social desirability, demographic and business-related data were also controlled, including (1) respondents' age; (2) gender; (3) highest qualification; (4) which industry their business operates in; (5) the size of their business, measured as employing 1-3, 4-10, 11-30, 31-99, or 100+ staff; (6) how many years their business has been operating; and (7) which generation business owner they are (i.e. first, second, third, etc.). Qualification options included secondary school, polytechnic course, trade certificate, bachelor's degree, master's degree and doctoral degree, in that order. Industries were classified as either professional services, trade services, marketing/sales, government, manufacturing, education, health, mining/drilling, retail or other. These variables are related to the focal study constructs: for example, firm performance is affected by entrepreneurs' age and gender (Shaw et al., 2009), their education (Doms et al., 2010) and parents' business ownership (Davidsson and Honig, 2003), as well as the age and size of their business (Coad et al., 2013) and characteristics of the industry where the business operates (Lumpkin and Dess, 2001). As such, these variables were controlled for during moderation analyses to partial out their effects (for a review, see Becker, 2005). Business size, for example, had a positive correlation with firm performance $(r=0.36, p<0.01)$ that without control would confound the interpretation of regression models.

\section{Common method variance}

Common method variance (CMV) issues were addressed both proactively in the study design and controlled statistically post-hoc following the procedures outlined by Podsakoff et al. (2003). Only previously validated scales were used where possible to ensure that participants' responses address the focal constructs, rather than an underlying common method variance. The response format was alternated to introduce a psychological separation between predictor and criterion variables and participants were assured that their information would remain anonymous to encourage candid responses.

Harman's single-factor test was used to ascertain if "either (a) a single factor will emerge from the factor analysis or (b) one general factor will account for the majority of covariance among the measures" (Podsakoff et al., 2003). Results of an exploratory factor analysis on all scale items revealed seven distinct factors, which accounted for $66.0 \%$ of the variance. The largest factor accounted for only $17.4 \%$ of the variance and therefore a single factor was not evident. A confirmatory factor analysis likewise revealed that a single-factor solution was a poor fit to the data: $\chi^{2} / \mathrm{df}(616)=2.94, p=0.000, \mathrm{GFI}=0.66$; $\mathrm{CFI}=0.75$; NFI $=0.67$; RMSEA $=0.09$. The results suggest that CMV issues are not a prevailing concern in the data.

\section{Analysis and results}

Descriptive statistics, bivariate correlations and reliability coefficients of the study variables are presented in Table 1 . All three latent construct scales were sufficiently reliable with Cronbach's coefficient alphas well above the recommended 0.70 threshold (Nunnally, 1978). Regression modelling was conducted with IBM SPSS v24. Measurement model fit was established with confirmatory factor analyses using IBM AMOS v24. Five different measurement models were evaluated, ranging from a single-factor solution to a five-factor model which included: psychological capital, social capital, entrepreneurial education, firm performance and social desirability. The hypothesized five factor model provided the best fit to the data $\chi^{2} / \mathrm{df}(607)=1.75, p=0.000, \mathrm{GFI}=0.80 ; \mathrm{CFI}=0.90 ; \mathrm{NFI}=0.80$; RMSEA $=0.06$.

Hypotheses 1-3 proposed that business owners' personal resources directly affect their firm performance. Pearson's correlations revealed significant positive associations between firm performance and the respondents' psychological capital $(r=0.38, p<0.01)$, social capital $(r=0.38, p<0.01)$ and their entrepreneurial education $(r=0.15, p<0.05)$. Linear regression 
IJEBR

26,5

1022

Table 1.

Correlation analysis of study variables

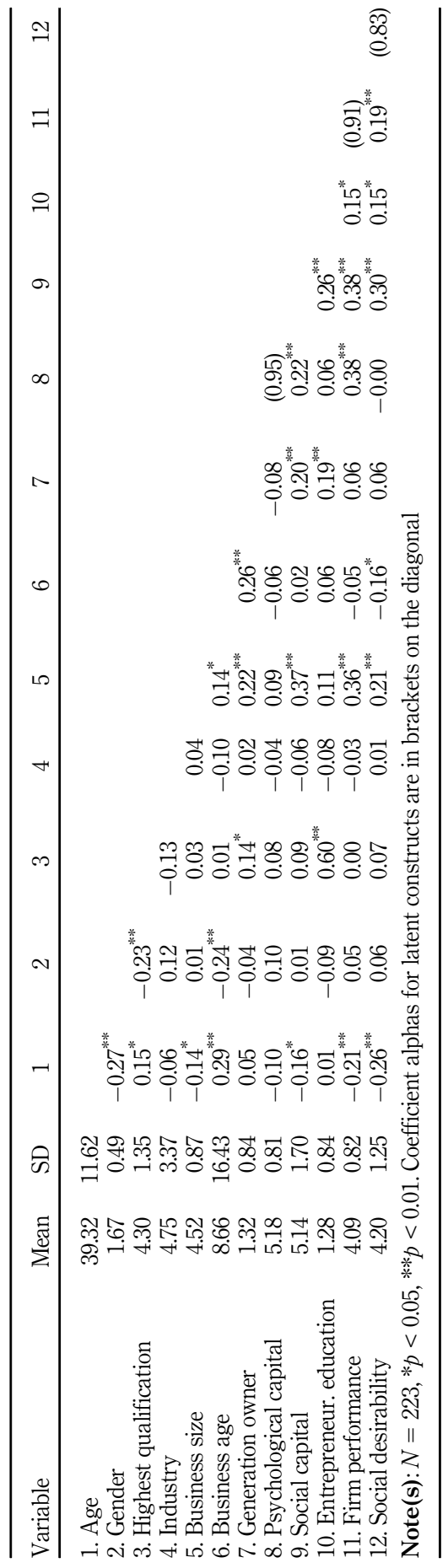


analysis then confirmed that these relations persist when demographic variables and social desirability are controlled; the results demonstrate that firm performance is predicted by business owners' psychological capital $(\beta=0.29, p<0.01)$, social capital $(\beta=0.22, p<0.01)$ and entrepreneurial education $(\beta=0.14, p<0.05)$. Therefore, the data support hypotheses $1-3$ that entrepreneurs' personal resources positively affect their firm performance.

Hypotheses 4-6 proposed that entrepreneurs' perceptions of the favorability of the local business environment positively moderate the effects of their psychological capital (H4), social capital (H5) and entrepreneurial education (H6) on firm performance. These moderation hypotheses were tested using multiple hierarchical regression analysis. The study variables were entered in three stages: Model 1 included only the control variables; Model 2 added the predictor $(a)$ and the moderator $(b)$; and Model 3 added the interaction term $(a \times b)$ to test for a moderation effect. The findings were confirmed by Preacher and Hayes's (2004) bootstrapping method with 10,000 bias-corrected samples using Hayes's (2013) PROCESS macro.

Every permutation of the three direct effects and the eight aspects of the business environment yielded 24 possible interactions. Each interaction was tested independently, rather than concurrently in a single model, to facilitate a robust assessment and allow for a clear interpretation of the results. Of the 24 interactions, only seven were significant and revealed a noteworthy pattern of results (see Tables 2-8 and Figure 2). The relationship between business owners' psychological capital and firm performance was moderated by their access to capital, university engagement and access to mentors. The effects of social capital on performance were moderated by local attitudes toward entrepreneurship and the effects of entrepreneurial education were moderated by government policy, access to labor and access to professional services. No significant moderation effects were evident from respondents' access to physical infrastructure.

The seven significant moderation effects were graphed using Hayes's (2013) PROCESS macro at one standard deviation above and below the mean (see Figures 3-9). The pattern of the two-way interactions was consistent across all seven moderation models and corresponds with hypotheses 4-6, that the positive relations between business owners' personal resources and firm performance are stronger when certain aspects of the business environment are

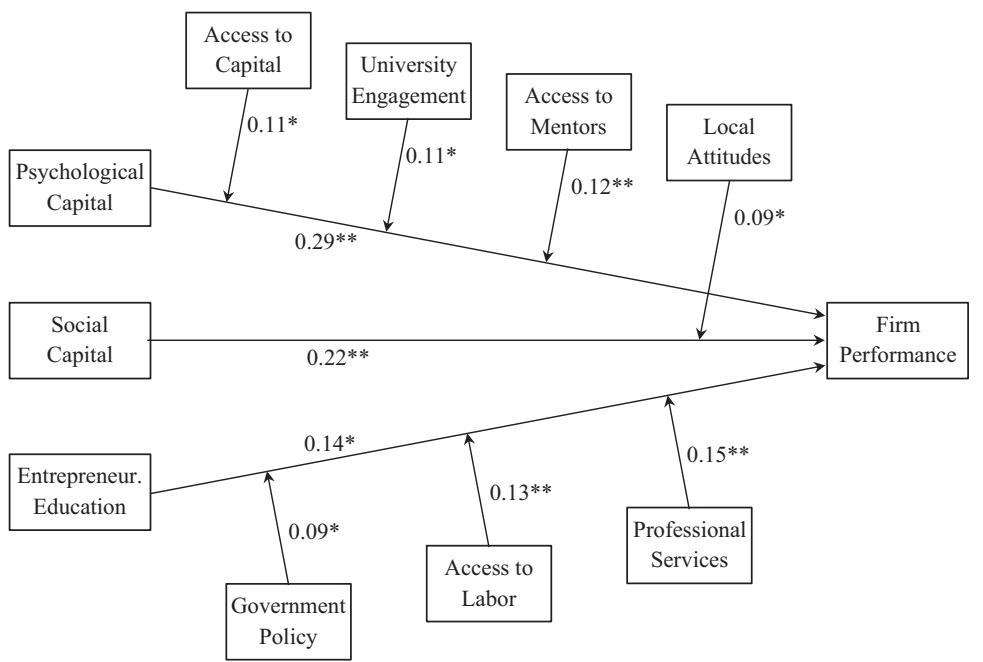

Note(s): $N=223, * p<0.05, * * p<0.01$. Non-significant moderation paths are suppressed for clarity
Entrepreneurial ecosystems

1023
Figure 2. Moderation analysis results 


\section{IJEBR 26,5}

$\underline{1024}$ B

Table 2.

Effect of psychological capital as moderated by access to capital

\begin{tabular}{|c|c|c|c|c|c|c|c|c|c|}
\hline \multirow[b]{2}{*}{ DV: firm performance } & \multicolumn{3}{|c|}{ Model 1} & \multicolumn{3}{|c|}{ Model 2} & \multicolumn{3}{|c|}{ Model 3} \\
\hline & $\beta$ & $\mathrm{SE}$ & $t$ & $\beta$ & $\mathrm{SE}$ & $t$ & $\beta$ & $\mathrm{SE}$ & $t$ \\
\hline Age & -0.01 & 0.01 & -1.84 & 0.00 & 0.00 & -0.79 & 0.00 & 0.00 & -0.89 \\
\hline Gender & 0.01 & 0.11 & 0.10 & -0.01 & 0.10 & -0.08 & 0.01 & 0.10 & 0.09 \\
\hline Highest qualification & 0.00 & 0.04 & 0.05 & -0.04 & 0.04 & -1.06 & -0.04 & 0.04 & -1.03 \\
\hline Industry & -0.01 & 0.02 & -0.89 & -0.01 & 0.01 & -0.82 & -0.01 & 0.01 & -0.98 \\
\hline Business size & $0.31^{* *}$ & 0.06 & 4.97 & $0.25^{* *}$ & 0.06 & 4.36 & $0.25^{* *}$ & 0.06 & 4.44 \\
\hline Business age & 0.00 & 0.00 & -0.74 & 0.00 & 0.00 & -1.30 & 0.00 & 0.00 & -1.13 \\
\hline Generation owner & 0.00 & 0.07 & 0.04 & 0.04 & 0.06 & 0.65 & 0.04 & 0.06 & 0.66 \\
\hline Social desirability & 0.05 & 0.04 & 1.11 & 0.02 & 0.04 & 0.46 & 0.01 & 0.04 & 0.28 \\
\hline Psychological capital (a) & & & & $0.23^{* *}$ & 0.05 & 4.83 & $0.22^{* *}$ & 0.05 & 4.66 \\
\hline Access to capital $(b)$ & & & & $0.25^{* *}$ & 0.05 & 4.96 & $0.22^{* *}$ & 0.05 & 4.34 \\
\hline Interaction $(a \times b)$ & & & & & & & $0.11^{*}$ & 0.05 & 2.28 \\
\hline & 0.16 & & & 0.35 & & & 0.37 & & \\
\hline Adj. $R^{2}$ & 0.13 & & & 0.32 & & & 0.34 & & \\
\hline$\Delta R^{2}$ & $0.16^{* *}$ & & & $0.19^{* *}$ & & & $0.02^{*}$ & & \\
\hline$\Delta F(\mathrm{df})$ & $5.22(8$, & 214) & & $31.03(10$ & 212) & & $5.22(1$ & 211) & \\
\hline
\end{tabular}

Table 3.

Effect of psychological capital as moderated by university engagement

\begin{tabular}{|c|c|c|c|c|c|c|c|c|c|}
\hline \multirow[b]{2}{*}{ DV: firm performance } & \multicolumn{3}{|c|}{ Model 1} & \multicolumn{3}{|c|}{ Model 2} & \multicolumn{3}{|c|}{ Model 3} \\
\hline & $\beta$ & $\mathrm{SE}$ & $t$ & $\beta$ & $\mathrm{SE}$ & $t$ & $\beta$ & $\mathrm{SE}$ & $t$ \\
\hline Age & -0.01 & 0.01 & -1.84 & -0.01 & 0.01 & -0.99 & -0.01 & 0.01 & -1.00 \\
\hline Gender & 0.01 & 0.11 & 0.10 & 0.00 & 0.11 & 0.02 & 0.01 & 0.11 & 0.11 \\
\hline Highest qualification & 0.00 & 0.04 & 0.05 & -0.03 & 0.04 & -0.87 & -0.03 & 0.04 & -0.68 \\
\hline Industry & -0.01 & 0.02 & -0.89 & -0.01 & 0.01 & -0.45 & 0.00 & 0.01 & -0.24 \\
\hline Business size & $0.31^{* *}$ & 0.06 & 4.97 & $0.25^{* *}$ & 0.06 & 4.23 & $0.25^{* *}$ & 0.06 & 4.26 \\
\hline Business age & 0.00 & 0.00 & -0.74 & 0.00 & 0.00 & -0.86 & 0.00 & 0.00 & -0.75 \\
\hline Generation owner & 0.00 & 0.07 & 0.04 & 0.03 & 0.06 & 0.51 & 0.02 & 0.06 & 0.36 \\
\hline Social desirability & 0.05 & 0.04 & 1.11 & 0.04 & 0.04 & 0.83 & 0.02 & 0.04 & 0.53 \\
\hline Psychological capital (a) & & & & $0.25^{* *}$ & 0.05 & 5.13 & $0.24^{* *}$ & 0.05 & 4.79 \\
\hline University engage. $(b)$ & & & & $0.16^{* * *}$ & 0.05 & 3.07 & $0.14^{*}$ & 0.05 & 2.51 \\
\hline Interaction $(a \times b)$ & & & & & & & $0.11^{*}$ & 0.05 & 2.37 \\
\hline & 0.16 & & & 0.31 & & & 0.33 & & \\
\hline Adj. $R^{2}$ & 0.13 & & & 0.28 & & & 0.29 & & \\
\hline$\Delta R^{2}$ & $0.16^{* *}$ & & & $0.15^{* *}$ & & & $0.02^{*}$ & & \\
\hline$\Delta F(\mathrm{df})$ & $5.22(8$, & 214) & & $22.22(10$ & 212) & & $5.61(1$ & ,211) & \\
\hline
\end{tabular}

more favorable, and weaker when the business environment is unfavorable. Therefore, hypotheses 4-6 were partially supported by the data that the favorability of the business environment either enables or inhibits entrepreneurs from leveraging their personal resources for firm performance. However, not all aspects of the environment moderated all three direct effects; indeed, each aspect of the business environment interacted with only one of the business owners' personal resources.

A series of models is presented instead of including all the moderators in a single model. To test for a moderation effect, three steps are required. First, any control variables are entered into the model; second, the independent and moderating variables are added; and third, the interaction term is added (independent $\times$ moderating). If adding the interaction term significantly alters the $R^{2}$ value from the previous step, then the moderation effect is significant. This process would need to be repeated for each 


\begin{tabular}{|c|c|c|c|c|c|c|c|c|c|c|}
\hline \multirow[b]{2}{*}{ DV: firm performance } & \multicolumn{3}{|c|}{ Model 1} & \multicolumn{3}{|c|}{ Model 2} & \multicolumn{3}{|c|}{ Model 3} & \multirow{2}{*}{$\begin{array}{r}\text { Entrepreneurial } \\
\text { ecosystems }\end{array}$} \\
\hline & $\beta$ & $\mathrm{SE}$ & $t$ & $\beta$ & $\mathrm{SE}$ & $t$ & $\beta$ & $\mathrm{SE}$ & $t$ & \\
\hline Age & -0.01 & 0.01 & -1.84 & -0.01 & 0.00 & -1.49 & -0.01 & 0.00 & -1.47 & \\
\hline Gender & 0.01 & 0.11 & 0.10 & -0.09 & 0.10 & -0.87 & -0.07 & 0.10 & -0.66 & \\
\hline Highest qualification & 0.00 & 0.04 & 0.05 & -0.04 & 0.04 & -1.09 & -0.03 & 0.04 & -0.93 & \\
\hline $\begin{array}{l}\text { Industry } \\
\end{array}$ & -0.01 & 0.02 & -0.89 & -0.02 & 0.01 & -1.29 & -0.02 & 0.01 & -1.07 & \\
\hline Business size & $0.31^{\text {*** }}$ & 0.06 & 4.97 & $0.23^{* *}$ & 0.06 & 4.01 & $0.22^{* *}$ & 0.06 & 3.81 & 1025 \\
\hline Business age & 0.00 & 0.00 & -0.74 & 0.00 & 0.00 & -1.16 & 0.00 & 0.00 & -1.03 & \\
\hline Generation owner & 0.00 & 0.07 & 0.04 & 0.06 & 0.06 & 0.96 & 0.04 & 0.06 & 0.64 & \\
\hline Social desirability & 0.05 & 0.04 & 1.11 & 0.04 & 0.04 & 0.91 & 0.02 & 0.04 & 0.54 & \\
\hline Psychological capital (a) & & & & $0.23^{* *}$ & 0.05 & 4.55 & $0.22^{* *}$ & 0.05 & 4.48 & \\
\hline Access to Mentors $(b)$ & & & & $0.22^{* *}$ & 0.05 & 4.27 & $0.22^{* *}$ & 0.05 & 4.33 & \\
\hline Interaction $(a \times b)$ & & & & & & & & 0.04 & 2.78 & \\
\hline$R^{2}$ & \multicolumn{3}{|l|}{0.16} & \multicolumn{3}{|l|}{0.33} & \multicolumn{3}{|l|}{0.36} & \\
\hline Adj. $R^{2}$ & \multicolumn{3}{|c|}{$\begin{array}{l}0.13 \\
0.16^{* * *}\end{array}$} & \multirow{2}{*}{\multicolumn{3}{|c|}{$\begin{array}{l}0.30 \\
0.17^{* *}\end{array}$}} & \multicolumn{3}{|l|}{0.32} & \\
\hline$\Delta R^{2}$ & \multirow{2}{*}{\multicolumn{3}{|c|}{$\begin{array}{l}0.16^{* *} \\
5.22(8,214)\end{array}$}} & & & & \multirow{2}{*}{\multicolumn{3}{|c|}{$\begin{array}{l}0.02 \\
7.70(11,211)\end{array}$}} & Effect of psychological \\
\hline$\Delta F(\mathrm{df})$ & & & & \multicolumn{3}{|c|}{$27.34(10,212)$} & & & & capital as moderated \\
\hline \multicolumn{10}{|c|}{ Note(s): $N=223, * p<0.05, * * p<0.01$} & \\
\hline
\end{tabular}

\begin{tabular}{|c|c|c|c|c|c|c|c|c|c|}
\hline \multirow[b]{2}{*}{ DV: firm performance } & \multicolumn{3}{|c|}{ Model 1} & \multicolumn{3}{|c|}{ Model 2} & \multicolumn{3}{|c|}{ Model 3} \\
\hline & $\beta$ & $\mathrm{SE}$ & $t$ & $\beta$ & $\mathrm{SE}$ & $t$ & $\beta$ & SE & $t$ \\
\hline Age & -0.01 & 0.01 & -1.84 & -0.01 & 0.01 & -1.13 & -0.01 & 0.01 & -1.16 \\
\hline Gender & 0.01 & 0.11 & 0.10 & 0.00 & 0.11 & 0.03 & 0.02 & 0.11 & 0.14 \\
\hline Highest qualification & 0.00 & 0.04 & 0.05 & -0.02 & 0.04 & -0.48 & -0.02 & 0.04 & -0.65 \\
\hline Industry & -0.01 & 0.02 & -0.89 & -0.01 & 0.01 & -0.58 & -0.01 & 0.01 & -0.75 \\
\hline Business size & $0.31^{\text {*** }}$ & 0.06 & 4.97 & $0.21^{* *}$ & 0.06 & 3.46 & $0.20^{* *}$ & 0.06 & 3.36 \\
\hline Business age & 0.00 & 0.00 & -0.74 & 0.00 & 0.00 & -0.78 & 0.00 & 0.00 & -0.80 \\
\hline Generation owner & 0.00 & 0.07 & 0.04 & -0.03 & 0.06 & -0.51 & -0.05 & 0.06 & -0.76 \\
\hline Social desirability & 0.05 & 0.04 & 1.11 & 0.03 & 0.04 & 0.68 & 0.01 & 0.04 & 0.12 \\
\hline Social capital $(a)$ & & & & $0.17^{* *}$ & 0.06 & 3.03 & $0.18^{* * *}$ & 0.06 & 3.20 \\
\hline Local attitudes (b) & & & & $0.24^{* *}$ & 0.05 & 4.77 & $0.23^{* *}$ & 0.05 & 4.72 \\
\hline Interaction $(a \times b)$ & & & & & & & $0.09^{*}$ & 0.05 & 2.00 \\
\hline$R^{2}$ & 0.16 & & & 0.29 & & & 0.31 & & \\
\hline Adj. $R^{2}$ & 0.13 & & & 0.26 & & & 0.27 & & \\
\hline$\Delta R^{2}$ & $0.16^{* *}$ & & & $0.13^{* *}$ & & & $0.01^{*}$ & & \\
\hline$\Delta F(\mathrm{df})$ & $5.22(8$, & 14) & & $19.54(10$ & 212) & & $4.02(1$ & 211) & \\
\hline
\end{tabular}

Table 5.

Effect of social capital as moderated by local attitudes

additional moderator. While it is technically possible to add more independent variables, moderators and interaction terms, one at a time, until they are all present in a single model, this would create a large and convoluted table of results. The sequence in which moderators are added would also affect the $R^{2}$ change for latter moderators, thereby confounding the assessment of each moderator's significance. Such a feature has not been built into Hayes's PROCESS macro and it would not be feasible to generate the interaction plots for each concurrent moderation effect, which are necessary for us to interpret the effects of each moderator. Therefore, each moderator is tested separately to facilitate a robust assessment and provide a clear interpretation of the results. However, the components of an entrepreneurial ecosystem are inter-related and isolating them for independent examination is not without limitations. 


\begin{tabular}{|c|c|c|c|c|c|c|c|c|c|c|}
\hline \multirow{2}{*}{$\begin{array}{l}\text { IJEBR } \\
26,5\end{array}$} & & \multicolumn{3}{|c|}{ Model 1} & \multicolumn{3}{|c|}{ Model 2} & \multicolumn{3}{|c|}{ Model 3} \\
\hline & DV: firm performance & $\beta$ & $\mathrm{SE}$ & $t$ & $\beta$ & SE & $t$ & $\beta$ & $\mathrm{SE}$ & $t$ \\
\hline \multirow[b]{5}{*}{1026} & Age & -0.01 & 0.01 & -1.84 & 0.00 & 0.01 & -0.58 & 0.00 & 0.01 & -0.30 \\
\hline & Gender & 0.01 & 0.11 & 0.10 & -0.02 & 0.11 & -0.21 & -0.02 & 0.11 & -0.18 \\
\hline & Highest qualification & 0.00 & 0.04 & 0.05 & -0.05 & 0.05 & -1.10 & -0.06 & 0.05 & -1.25 \\
\hline & Industry & -0.01 & 0.02 & -0.89 & -0.02 & 0.02 & -1.09 & -0.02 & 0.02 & -1.10 \\
\hline & Business size & $0.31^{* *}$ & 0.06 & 4.97 & $0.30^{* *}$ & 0.06 & 5.06 & $0.30^{* *}$ & 0.06 & 5.02 \\
\hline \multirow{10}{*}{$\begin{array}{l}\text { Table } 6 \text {. } \\
\text { Effect of } \\
\text { entrepreneurial } \\
\text { education as } \\
\text { moderated by } \\
\text { government policy }\end{array}$} & $\begin{array}{l}\text { Business age } \\
\text { Generation owner }\end{array}$ & $\begin{array}{l}0.00 \\
0.00\end{array}$ & $\begin{array}{l}0.00 \\
0.07\end{array}$ & $\begin{array}{r}-0.74 \\
0.04\end{array}$ & $\begin{array}{r}0.00 \\
-0.02\end{array}$ & $\begin{array}{l}0.00 \\
0.06\end{array}$ & $\begin{array}{l}-0.90 \\
-0.29\end{array}$ & $\begin{array}{r}0.00 \\
-0.02\end{array}$ & $\begin{array}{l}0.00 \\
0.06\end{array}$ & $\begin{array}{l}-0.95 \\
-0.24\end{array}$ \\
\hline & Social desirability & 0.05 & 0.04 & $\begin{array}{l}0.04 \\
1.11\end{array}$ & $\begin{array}{r}-0.02 \\
0.01\end{array}$ & 0.04 & $\begin{array}{r}-0.29 \\
0.34\end{array}$ & $\begin{array}{r}-0.02 \\
0.01\end{array}$ & 0.04 & $\begin{array}{r}-0.24 \\
0.33\end{array}$ \\
\hline & Entrepren. education $(a)$ & & & & 0.10 & 0.06 & 1.65 & 0.11 & 0.06 & 1.70 \\
\hline & Government policy $(b)$ & & & & $0.25^{* *}$ & 0.05 & 4.80 & $0.25^{* *}$ & 0.05 & 4.88 \\
\hline & Interaction $(a \times b)$ & \multirow{2}{*}{\multicolumn{3}{|c|}{0.16}} & \multirow{2}{*}{\multicolumn{3}{|c|}{026}} & $0.09^{*}$ & 0.05 & 2.01 \\
\hline & $R^{2}$ & & & & & & & \multicolumn{3}{|l|}{0.27} \\
\hline & Adj. $R^{2}$ & \multicolumn{3}{|l|}{0.13} & \multicolumn{3}{|c|}{0.23} & \multirow{2}{*}{\multicolumn{3}{|c|}{$\begin{array}{l}0.24 \\
0.01^{*}\end{array}$}} \\
\hline & $\Delta R^{2}$ & \multicolumn{3}{|c|}{$0.16^{* *}$} & \multirow{2}{*}{\multicolumn{3}{|c|}{$\begin{array}{l}0.10^{\text {** }} \\
13.95(10,212)\end{array}$}} & & & \\
\hline & $\Delta F(\mathrm{df})$ & \multicolumn{3}{|c|}{$5.22(8,214)$} & & & & \multicolumn{3}{|c|}{$4.05(11,211)$} \\
\hline & \multicolumn{7}{|c|}{$\operatorname{Note}(\mathbf{s}): N=223, * p<0.05, * * p<0.01$} & & & \\
\hline
\end{tabular}

Table 7.

Effect of entrepreneurial education as moderated by access to labor

\begin{tabular}{|c|c|c|c|c|c|c|c|c|c|}
\hline \multirow[b]{2}{*}{ DV: firm performance } & \multicolumn{3}{|c|}{ Model 1} & \multicolumn{3}{|c|}{ Model 2} & \multicolumn{3}{|c|}{ Model 3} \\
\hline & $\beta$ & $\mathrm{SE}$ & $t$ & $\beta$ & $\mathrm{SE}$ & $t$ & $\beta$ & SE & $t$ \\
\hline Age & -0.01 & 0.01 & -1.84 & 0.00 & 0.01 & -0.62 & 0.00 & 0.01 & -0.47 \\
\hline Gender & 0.01 & 0.11 & 0.10 & 0.04 & 0.11 & 0.41 & 0.02 & 0.11 & 0.22 \\
\hline Highest qualification & 0.00 & 0.04 & 0.05 & -0.07 & 0.05 & -1.48 & -0.07 & 0.05 & -1.56 \\
\hline Industry & -0.01 & 0.02 & -0.89 & -0.02 & 0.02 & -1.02 & -0.02 & 0.01 & -1.20 \\
\hline Business size & $0.31^{* *}$ & 0.06 & 4.97 & $0.24^{* * *}$ & 0.06 & 3.90 & $0.24^{* * *}$ & 0.06 & 4.00 \\
\hline Business age & 0.00 & 0.00 & -0.74 & 0.00 & 0.00 & -1.29 & -0.01 & 0.00 & -1.49 \\
\hline Generation owner & 0.00 & 0.07 & 0.04 & -0.01 & 0.06 & -0.23 & -0.02 & 0.06 & -0.25 \\
\hline Social desirability & 0.05 & 0.04 & 1.11 & 0.03 & 0.04 & 0.69 & 0.03 & 0.04 & 0.73 \\
\hline Entrepren. education $(a)$ & & & & 0.12 & 0.06 & 1.93 & $0.11_{* *}$ & 0.06 & 1.85 \\
\hline Access to labor $(b)$ & & & & $0.28^{* *}$ & 0.05 & 5.28 & $0.31^{* * *}$ & 0.05 & 5.83 \\
\hline Interaction $(a \times b)$ & & & & & & & $0.13^{* *}$ & 0.05 & 2.77 \\
\hline$R^{2}$ & 0.16 & & & 0.28 & & & 0.30 & & \\
\hline Adj. $R^{2}$ & 0.13 & & & 0.24 & & & 0.26 & & \\
\hline$\Delta R^{2}$ & $0.16^{* *}$ & & & $0.11^{\text {** }}$ & & & $0.03^{\text {** }}$ & & \\
\hline$\Delta F(\mathrm{df})$ & $5.22(8$ & 214) & & $16.42(1$ & 212) & & $7.65(11$ & 211) & \\
\hline $\operatorname{Note}(\mathbf{s}): N=223,{ }^{*} p<$ & $5, * * p<1$ & & & & & & & & \\
\hline
\end{tabular}

\section{Discussion}

The present work explains how entrepreneurs' personal resources affect their firm performance and how aspects of the business environment interact with these relations to enable or inhibit productive entrepreneurship. The results reveal that business owners' psychological capital, social capital and entrepreneurial education all have significant positive effects on individual firm performance. These findings are underpinned by, and congruent with, psychological resource theory (Hobfoll, 2002), social capital theory (Lin, 2002) and human capital theory (Martin et al., 2013). The favorability of the business environment moderates these relations so that the positive effects are stronger when the environment is more favorable, which is consistent with the major tenets of ecological systems theory (Bronfenbrenner, 1979). Seven key aspects of the business environment interact with 


\begin{tabular}{|c|c|c|c|c|c|c|c|c|c|c|}
\hline \multirow[b]{2}{*}{ DV: firm performance } & \multicolumn{3}{|c|}{ Model 1} & \multicolumn{3}{|c|}{ Model 2} & \multicolumn{3}{|c|}{ Model 3} & \multirow{2}{*}{$\begin{array}{r}\text { Entrepreneurial } \\
\text { ecosystems }\end{array}$} \\
\hline & $\beta$ & $\mathrm{SE}$ & $t$ & $\beta$ & $\mathrm{SE}$ & $t$ & $\beta$ & $\mathrm{SE}$ & $t$ & \\
\hline Age & -0.01 & 0.01 & -1.84 & -0.01 & 0.01 & -1.31 & -0.01 & 0.01 & -1.07 & \multirow{11}{*}{1027} \\
\hline Gender & 0.01 & 0.11 & 0.10 & -0.01 & 0.11 & -0.13 & -0.02 & 0.11 & -0.21 & \\
\hline Highest qualification & 0.00 & 0.04 & 0.05 & -0.06 & 0.05 & -1.20 & -0.06 & 0.05 & -1.20 & \\
\hline Industry & -0.01 & 0.02 & -0.89 & -0.01 & 0.02 & -0.82 & -0.01 & 0.02 & -0.76 & \\
\hline Business size & $0.31^{* *}$ & 0.06 & 4.97 & $0.26^{* *}$ & 0.06 & 4.32 & $0.27^{* *}$ & 0.06 & 4.44 & \\
\hline Business age & 0.00 & 0.00 & -0.74 & 0.00 & 0.00 & -0.96 & 0.00 & 0.00 & -1.15 & \\
\hline Generation owner & 0.00 & 0.07 & 0.04 & -0.03 & 0.06 & -0.41 & -0.02 & 0.06 & -0.35 & \\
\hline Social desirability & 0.05 & 0.04 & 1.11 & 0.03 & 0.04 & 0.64 & 0.02 & 0.04 & 0.45 & \\
\hline Entrepren. education (a) & & & & 0.12 & 0.06 & 1.91 & 0.11 & 0.06 & 1.81 & \\
\hline Professional services $(b)$ & & & & $0.22^{* *}$ & 0.05 & 4.20 & $0.22^{* * *}$ & 0.05 & 4.41 & \\
\hline Interaction $(a \times b)$ & & & & & & & $0.15^{* * *}$ & 0.05 & 2.84 & \\
\hline$R^{2}$ & \multicolumn{3}{|l|}{0.16} & \multicolumn{3}{|l|}{0.24} & \multicolumn{3}{|l|}{0.27} & $\mathrm{~F}$ \\
\hline Adj. $R^{2}$ & \multicolumn{3}{|l|}{0.13} & \multicolumn{3}{|c|}{0.21} & \multicolumn{3}{|c|}{0.23} & \\
\hline$\Delta R^{2}$ & \multicolumn{3}{|c|}{$0.16^{* *}$} & \multirow{2}{*}{\multicolumn{3}{|c|}{$\begin{array}{l}0.08^{* *} \\
11.20(10,212)\end{array}$}} & \multirow{2}{*}{\multicolumn{3}{|c|}{$\begin{array}{l}0.03^{* * *} \\
8.08(11,211)\end{array}$}} & $\begin{array}{l}\text { entrepreneurlal } \\
\text { education as }\end{array}$ \\
\hline$\Delta F(\mathrm{df})$ & \multicolumn{3}{|c|}{$5.22(8,214)$} & \multirow{2}{*}{\multicolumn{3}{|c|}{$11.20(10,212)$}} & & & $8.08(11,211)$ & moderated by \\
\hline \multicolumn{7}{|c|}{$\operatorname{Note}(\mathbf{s}): N=223,{ }^{*} p<0.05, * * p<0.01$} & & & & professional services \\
\hline
\end{tabular}

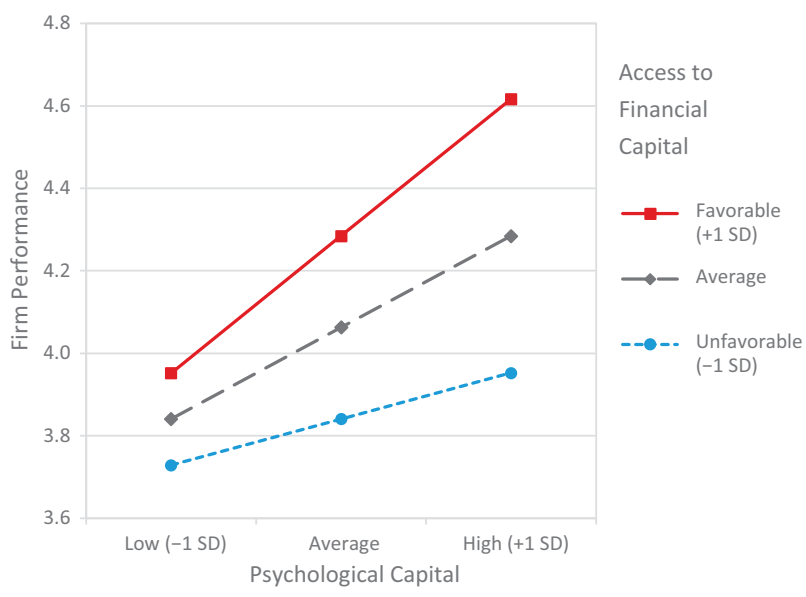

Figure 3.

Psychological capital moderated by access to capital

entrepreneurs' personal resources to reveal a noteworthy pattern of results. The interpretation of these findings against a backdrop of the literature provides important advances to theory.

Applying psychological resource theory (Hobfoll, 2002) suggests that strong psychological capital will always be beneficial for entrepreneurs and empirical research supports such a claim (e.g. Hmieleski and Carr, 2008). Yet the positive effects of business owners' psychological capital on their firm performance are moderated in the present study by the favorability of their access to capital, local university engagement and the availability of mentorship in the business environment. Business owners' mental resources, such as their hope, optimism, resilience and self-efficacy, have a stronger effect on their firm performance 


\section{IJEBR 26,5}

\section{8}

Figure 4.

Psychological capital moderated by university engagement
Figure 5.

Psychological capital moderated by access to mentors
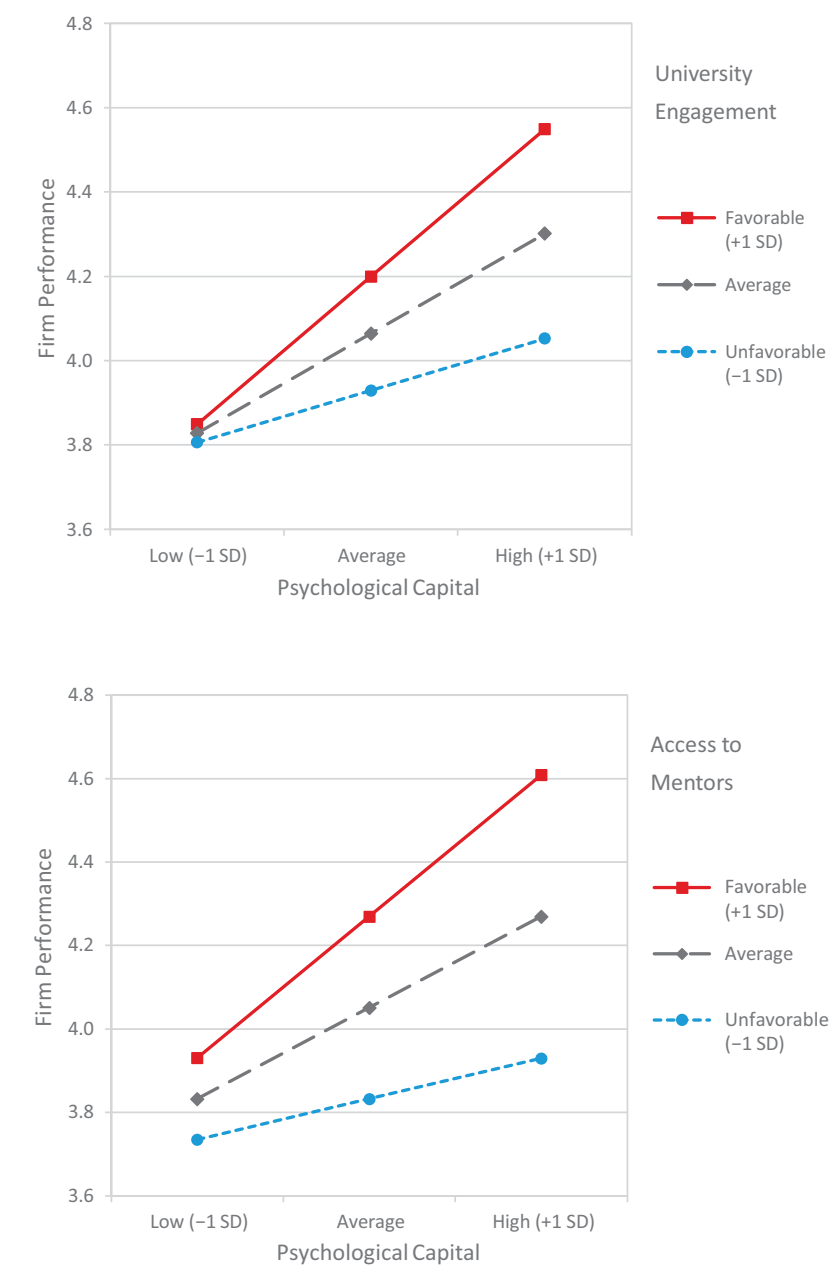

when the local business environment offers them opportunities to leverage these resources. The present results therefore indicate that psychological capital is much more useful when business owners can apply it to pursue investment funding opportunities, connect with universities to stimulate innovation or establish valuable mentoring relationships. Such pursuits require tenacity and perseverance (Hayward et al., 2010): it is typical to go through multiple rounds of rejection when seeking venture capital; successfully navigating complex university bureaucracies can be daunting for new business owners; and contacting experienced business leaders for guidance and support can be intimidating. Aspects of the business context thus alter the application of psychological resource theory such that entrepreneurs with strong psychological capital excel when the business environment offers them opportunities to leverage this valuable personal resource. Regional entrepreneurial ecosystems within which individual firms are embedded should therefore provide access to venture capital, business mentors and university engagement for individual entrepreneurs to make the most of their psychological capital. 


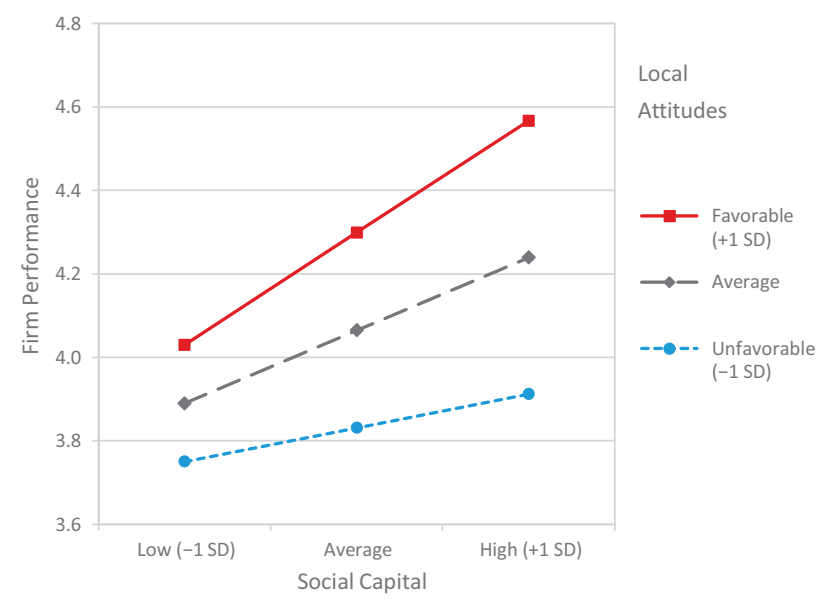

Entrepreneurial ecosystems

1029

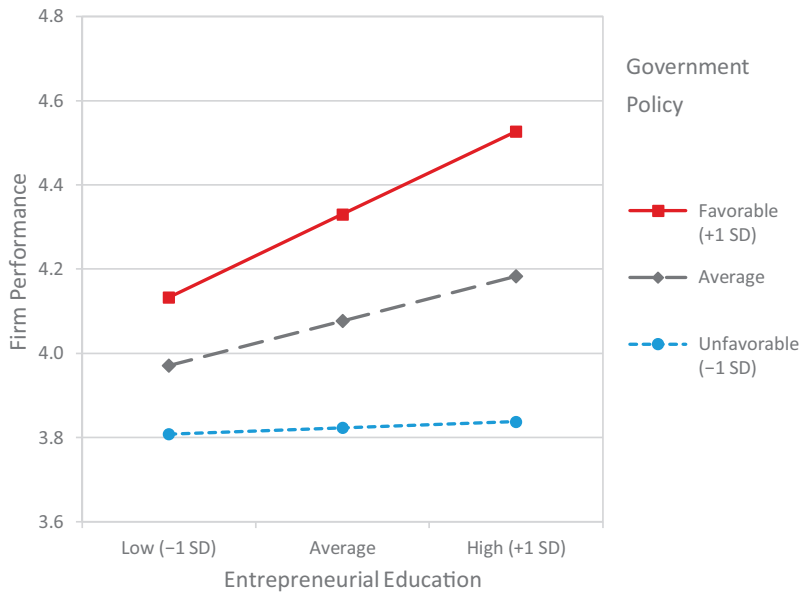

Figure 6.

Social capital moderated by local attitudes

Figure 7.

Entrepreneurial education moderated by government policy

Human capital theory (Martin et al., 2013) suggests that, similarly to developing psychological capital, pursuing entrepreneurial education is beneficial for business owners (for a review, see Marvel et al., 2016). Yet based on the present analyses, business owners can obtain much more positive effects on firm performance if local government policy is also favorable and they have access to labor and professional services. Entrepreneurial education, among other skills, teaches business owners to navigate local legislative requirements, to attract and retain talented staff and to outsource peripheral business processes to professional service providers on favorable terms (Piperopoulos and Dimov, 2015; Rideout and Gray, 2013). However, learning that local government policy disadvantages entrepreneurs; that the region struggles to attract high-skilled labor; or that professional services are either unavailable or priced out of reach, might not improve firm performance. In fact, if an entrepreneurial ecosystem has very poor access to labor and professional services, the opportunity cost of investing personal resources into pursuing entrepreneurial education appears to harm individual firm performance. The present results therefore begin to explain 


\section{IJEBR 26,5}

\section{0}

Figure 8.

Entrepreneurial education moderated by access to labor

\section{Figure 9.}

Entrepreneurial education moderated by professional services
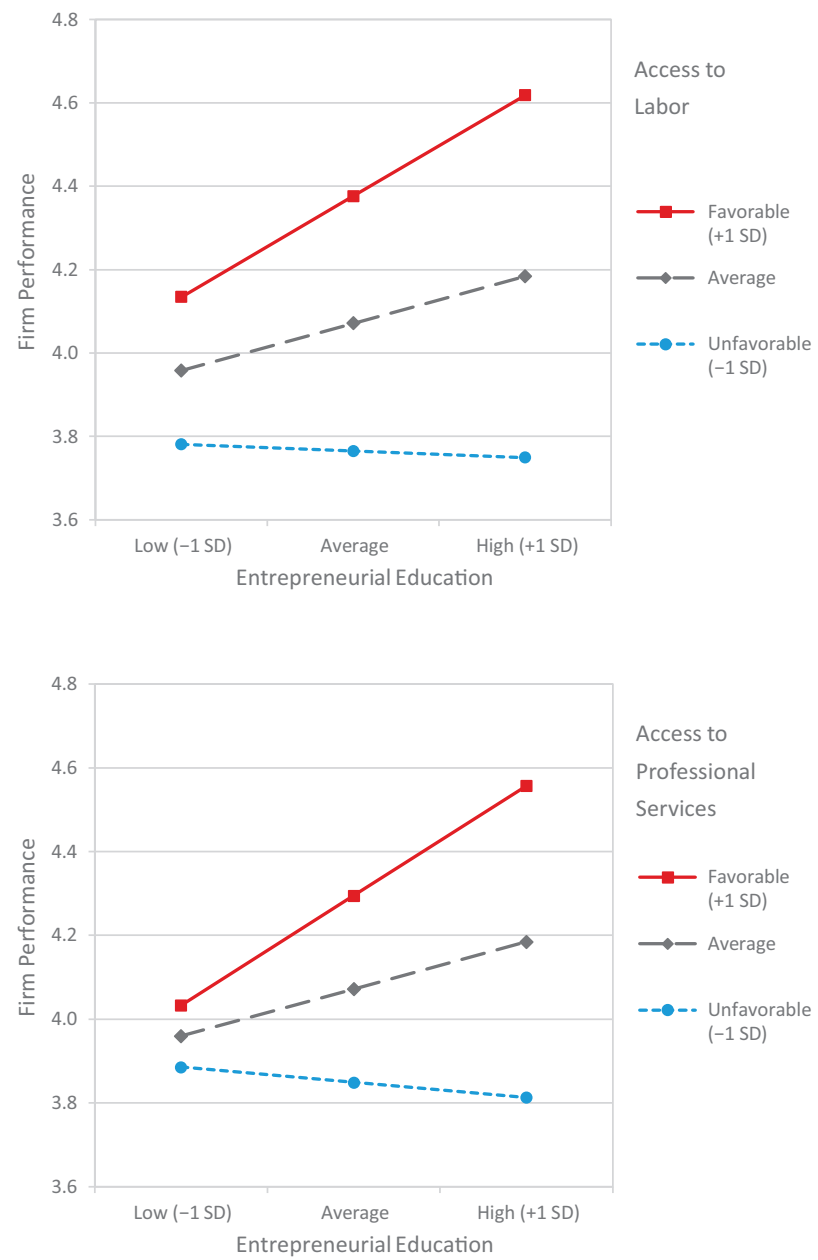

how and under what conditions human capital theory applies to new business ownership contexts. Hence, entrepreneurial ecosystems should provide favorable government policy and ready access to labor and professional services for local business owners to most effectively translate their entrepreneurial education into firm performance.

Applying social capital theory (Lin, 2002) suggests that developing social capital will advantage business owners by providing access to a host of resources embedded within their networks. However, the effects of business owners' social capital on their firm performance were moderated in the present study by local attitudes toward entrepreneurship: whether the community sees business ownership as beneficial and desirable. Ecosystems that are characterized by favorable local perceptions of entrepreneurial activity enable business owners to better leverage their social capital for improved firm performance. Accessing the resources embedded within strong and diverse social networks is therefore easier if people in that region are generally amenable to entrepreneurial ventures. While the positive effects of business owners' psychological capital and entrepreneurial education are significantly 
affected by multiple aspects of the local business environment in this study, social capital appears to be much less susceptible to such contextual shocks. Hence, business owners who find themselves entrenched in an overwhelmingly unfavorable business environment may focus on developing social capital as an avenue for improving firm performance. However, these results also temper social capital theory (Lin, 2002) - the value of social capital is not ubiquitous across entrepreneurial contexts and depends on local attitudes toward business ownership. Communities that are critical of entrepreneurial ventures may reduce the firm performance returns on business owners' social capital gains; that is, building stronger ties with a more diverse social network will net fewer resources when the local attitudes toward new ventures are unfavorable. Entrepreneurial ecosystems should therefore work to develop positive perceptions of business ownership in the community for individual entrepreneurs to best leverage their social capital.

The second phase of ecological systems theory explains that context-individual interactions best predict development (Tudge et al., 2009) and is consistent with the positive moderation effects observed in the data. The favorability of the macro business environment interacted with individual business owners' personal resources to predict firm performance. The results of the present research therefore support the application of ecological systems theory (Bronfenbrenner, 1979) as a core model underpinning entrepreneurial ecosystems. This paper thereby extends ecological systems theory to offer researchers a viable theoretical framework for examining the antecedents, outcomes, mechanisms and interactions within entrepreneurial ecosystems. The findings are encouraging and suggest that entrepreneurial ecosystems theory should consider both the agents and the context, rather than either or in isolation: we need to put the entrepreneur back into entrepreneurial ecosystems theory.

In the present study, entrepreneurs' perceptions of business environment favorability interact with the relations between their personal resources and firm performance, not an objective assessment of the business environment itself, which is consistent with subjective entrepreneurial theory (Mahoney and Michael, 2005). Therefore, some of the issues faced by business owners may be perceptual, constrained by limited information and their bounded rationality. This has important policy implications: local governments seeking to stimulate productive entrepreneurship may not necessarily need to improve aspects of the business environment if they are sufficiently favorable, but rather channel resources into building awareness of the advantages that are already available to local business owners.

Examining the magnitude of the interaction term coefficients reveals that none of the seven significant moderators outperform the others, with comparable effect sizes across all components of the business environment. An important interpretation for entrepreneurial ecosystem development is that all aspects of the business environment are similarly relevant. One exception is access to physical infrastructure, which did not interact significantly with any of the business owners' three personal resources tested in the current study. Audretsch, Heger and Veith (2015) explain that the presence and quality of local physical infrastructure influences potential entrepreneurs' decision to start a business. However, based on the present data, infrastructure favorability does not appear to enable or inhibit existing business owners from translating their personal resources into firm performance. One explanation is that firms have such ubiquitous access to relevant physical infrastructure across the major economic centers in Australia to have no observable effect on the application of entrepreneurs' personal resources. However, comparing regions with different infrastructural profiles may yet reveal significant interactions.

By delineating how contextual factors interact with performance outcomes, the results of this study begin to explain why certain regions might enable productive entrepreneurial activity more readily than others, despite similar access to natural resources and comparable demographic, economic and political profiles. 
IJEBR

26,5

1032

\section{Practical implications}

The present framework advances not only the academic development of this nascent concept, but also provides practical utility. Policymakers can apply these new insights to conceive of economic regions as entrepreneurial ecosystems, complete with eight distinct domains of competence: government policy, access to capital, access to labor, access to professional services, physical infrastructure, university engagement, local attitudes toward entrepreneurship and access to mentors. Such contextual factors synergize with the personal resources of local business owners to enable more productive entrepreneurship. Applying the empirical model presented in this paper allows regional government organizations to identify which aspects of their business environment are areas of strength and which are wanting (Liguori et al., 2019).

Many existing entrepreneurial ecosystems are stuck in a state of subsistence, unable to achieve supernormal profits that generate growth. The results of this study suggest that such ecosystems are deficient in one (or more) crucial aspects of the business environment which are stifling progress. Rectifying deficient business conditions will improve individual firm performance and thereby propel the region into a higher state of economic development (Acs et al., 2014). Therefore, this paper contributes with an empirical framework for assessing local business conditions that either enable or inhibit productive entrepreneurship. Policymakers can apply this model to garner a more nuanced understanding of their municipality and thereby make better informed decisions about where to deploy strategic resources to support regional economic development.

The results also reveal that entrepreneurs' personal resources are not of equal value. For example, the direct effect of psychological capital on firm performance is two times that of entrepreneurial education and yet governments are keen to promote entrepreneurship courses (Valerio et al., 2014), but pay considerably less attention to developing local entrepreneurs' positive mental states. Moreover, some personal resources are more susceptible to the favorability of the local business environment than others. Social capital, for example, was only affected by local attitudes toward entrepreneurship. As such, building entrepreneurs' social capital may improve their individual firm performance even in the most challenging business contexts. Incorporating these findings into public policy development can therefore steer government agencies toward more effective resource allocation decisions that align with local conditions.

\section{Limitations and future research}

This study has several limitations. First, the terms entrepreneur and business owner are used interchangeably and yet may be distinct. Wagener et al. (2010) describe entrepreneurs as having a "psychological profile that is consistent with innovation, growth and profit" (p. 1,522), whereas non-entrepreneurial business owners tend toward stability. Therefore, some of the respondents may be possessed of a more entrepreneurial mindset, which could be another factor driving their individual firm performance and thus offers an alternative explanation of the results. Business owners may also not necessarily qualify as entrepreneurs if they have acquired an existing company. However, most of the participants were first generation owners of new small businesses, so it is likely that most of the respondents were owner-operators and engaged in the entrepreneurial discovery, evaluation and exploitation of opportunities.

Second is the issue of generalizability. The data were collected within Australia and should be applied with caution to international contexts. Cultural elements may significantly alter the pattern of results (Stephan and Pathak, 2016): for example, determining how personal resources are deployed; affecting the interpretation of business environment favorability; or augmenting how firm outcomes are quantified. Further investigation is 
warranted to assess whether these relations hold across a range of different countries. Replicating the present study in a series of different regions will enable researchers to aggregate business owners' individual level perceptions of environment favorability into ecosystem level measures to test for cross-level moderation effects and tease out potential between-group differences.

The third limitation is related to the measurement of firm performance. An ideal assessment would capture objective data along key indicators for a robust result. However, SMEs are not required to report performance data and business owners are typically reluctant to volunteer it for research purposes. Moreover, the information can be strategic, inconsistent or simply unknown. Measuring firm performance based on business owners' perception is a functional bypass and not without risks. Controlling for respondents' social desirability bias goes some way toward mitigating that risk and perceptual measures of firm performance correlate strongly with object assessments (Tomaskovic-Devey et al., 1994). However, future studies may benefit from more objective, numeric measurements of performance.

Fourth is the possibility of competing explanations. This paper follows a dominant trend in entrepreneurship research by testing business owners' individual level resources as predictors of their firm performance (e.g. Miao et al., 2017); and yet unexamined firm-level factors may likewise play an important role in the observed interactions. Advances in competitive advantage offer a number of relevant firm-level constructs and frameworks, including resource-based views (Peteraf, 1993) and dynamic capabilities (Teece et al., 1997). The results of the present study do not preclude the possibility that other firm-level factors are decisive in determining firm performance. However, such analyses lie outside the scope of this paper. Future researchers may find it fruitful to adapt the individual-level model presented here to explore how firm-level antecedents of performance interact with environment favorability. The effects on other firm-level outcomes beyond economic performance are also worth examining, such as innovation or the pursuit of prosocial, environmental and sustainability initiatives.

The components of entrepreneurial ecosystems are interrelated and isolating these variables for independent moderation testing incurs limitations. Spigel (2017) states that "ecosystems are defined by the connections between the attributes that produce them and the benefits they provide to entrepreneurs" (p. 66). Therefore, relevant interactions may exist within individual- and ecosystem-level variables: for example, business owners with higher psychological capital might be more likely to pursue networking opportunities that develop social capital; or local attitudes toward entrepreneurship may affect the favorability of government policy for new ventures. However, sound theoretical arguments support the interactions in this entrepreneurial ecosystem model, and testing for additional effects is beyond the study scope. Future researchers are encouraged to extend the present individuallevel framework to explore the relations within and between ecosystem components, as well as collecting multi-level data across several distinct ecosystems to examine potential crosslevel interactions.

\section{Conclusion}

This paper offers important advances for entrepreneurial ecosystem research, and the results have meaningful practical implications for policymakers. The present work extends current theory by empirically testing a set of mechanisms that work within entrepreneurial ecosystems to affect the performance of member firms. The results show that the positive effects of business owners' psychological capital, social capital and entrepreneurial education are moderated by specific aspects of the business environment. These findings challenge the idea that favorable business conditions generate performance, instead revealing that 
IJEBR

26,5

1034

favorable aspects of the local business environment enable entrepreneurs to more effectively translate their personal resources into firm performance. Seven entrepreneurial ecosystem components demonstrate significant interaction effects, including: access to capital, university engagement, access to mentors, local attitudes toward entrepreneurship, government policy, access to labor and access to professional services. This study thereby explains under what conditions individual business owners can make the most of their personal resources, suggesting a complex interplay where one size does not fit all.

\section{References}

Acs, Z.J., Autio, E. and Szerb, L. (2014), "National systems of entrepreneurship: measurement issues and policy implications", Research Policy, Vol. 43 No. 3, pp. 476-494.

Acs, Z.J., Stam, E., Audretsch, D.B. and O'Connor, A. (2017), "The lineages of the entrepreneurial ecosystem approach", Small Business Economics, Vol. 49 No. 1, pp. 1-10.

Audretsch, D.B., Heger, D. and Veith, T. (2015), "Infrastructure and entrepreneurship”, Small Business Economics, Vol. 44 No. 2, pp. 219-230.

Audretsch, D.B. (2009), "Emergence of the entrepreneurial society", Business Horizons, Vol. 52 No. 5, pp. 505-511.

Auerswald, P.E. and Dani, L. (2017), "The adaptive life cycle of entrepreneurial ecosystems: the biotechnology cluster", Small Business Economics, Vol. 49 No. 1, pp. 97-117.

Australian Bureau of Statistics (2020), "Labour force, Australia, Feb 2020", available at: https://www. abs.gov.au/ausstats/abs@.nsf/mf/6202.0 (accessed 27 March 2020).

Australian Small Business and Family Enterprise Ombudsman (2019), Small Business Counts: Small Business in the Australian Economy, Australian Small Business and Family Enterprise Ombudsman, Australia.

Autio, E., Kenney, M., Mustar, P., Siegel, D. and Wright, M. (2014), "Entrepreneurial innovation: the importance of context”, Research Policy, Vol. 43 No. 7, pp. 1097-1108.

Avey, J.B., Luthans, F. and Jensen, S.M. (2009), "Psychological capital: a positive resource for combating employee stress and turnover", Human Resource Management, Vol. 48 No. 5, pp. 677-693.

Bae, T.J., Qian, S., Miao, C. and Fiet, J.O. (2014), "The relationship between entrepreneurship education and entrepreneurial intentions: a meta-analytic review", Entrepreneurship: Theory and Practice, Vol. 38 No. 2, pp. 217-254.

Barney, J. (1991), "Firm resources and sustained competitive advantage", Journal of Management, Vol. 17 No. 1, pp. 99-120.

Batjargal, B. (2003), "Social capital and entrepreneurial performance in Russia: a longitudinal study", Organization Studies, Vol. 24 No. 4, pp. 535-556.

Bauernschuster, S., Falck, O. and Heblich, S. (2010), "Social capital access and entrepreneurship", Journal of Economic Behavior and Organization, Vol. 76 No. 3, pp. 821-833.

Baumol, W.J. (1990), "Entrepreneurship: productive, unproductive, and destructive", Journal of Business Venturing, Vol. 11 No. 1, pp. 3-22.

Becker, T.E. (2005), "Potential problems in the statistical control of variables in organizational research: a qualitative analysis with recommendations", Organizational Research Methods, Vol. 8 No. 3, pp. 274-289.

Bisgaard, M. (2015), "Bias will find a way: economic perceptions, attributions of blame, and partisanmotivated reasoning during crisis", The Journal of Politics, Vol. 77 No. 3, pp. 849-860.

Björklund, T.A. and Krueger, N.F. (2016), "Generating resources through co-evolution of entrepreneurs and ecosystems", Journal of Enterprising Communities: People and Places in the Global Economy, Vol. 10 No. 4, pp. 477-498. 
Boon, H.J., Cottrell, A., King, D., Stevenson, R.B. and Millar, J. (2012), "Bronfenbrenner's bioecological theory for modelling community resilience to natural disasters", Natural Hazards, Vol. 60 No. 2, pp. 381-408.

Bronfenbrenner, U. (1979), The Ecology of Human Development: Experiments by Nature and Design, Harvard University Press, Cambridge, MA.

Bronfenbrenner, U. (1989), "Ecological systems theory", in Vasta, R. (Ed.), Annals of Child Development, Vol. 6, JAI Press, Greenwich, CT, pp. 187-249.

Chen, G., Gully, S.M. and Eden, D. (2001), "Validation of a new general self-efficacy scale", Organizational Research Methods, Vol. 4 No. 1, pp. 62-83.

Coad, A., Segarra, A. and Teruel, M. (2013), "Like milk or wine: does firm performance improve with age?", Structural Change and Economic Dynamics, Vol. 24, pp. 173-189.

Cohen, B. (2006), "Sustainable valley entrepreneurial ecosystems", Business Strategy and the Environment, Vol. 15 No. 1, pp. 1-14.

Cools, E. and Van den Broeck, H. (2007), "The hunt for the heffalump continues: can trait and cognitive characteristics predict entrepreneurial orientation?", Journal of Small Business Strategy, Vol. 18 No. 2, pp. 23-41.

Crook, T.R., Todd, S.Y., Combs, J.G., Woehr, D.J. and Ketchen Jr, D.J. (2011), "Does human capital matter? A meta-analysis of the relationship between human capital and firm performance", Journal of Applied Psychology, Vol. 96 No. 3, pp. 443-456.

Dalecki, M.G., Whitehead, J.C. and Blomquist, G.C. (1993), "Sample non-response bias and aggregate benefits in contingent valuation: an examination of early, late and non-respondents", Journal of Environmental Management, Vol. 38 No. 2, pp. 133-143.

Davidsson, P. and Honig, B. (2003), "The role of social and human capital among nascent entrepreneurs", Journal of Business Venturing, Vol. 18 No. 3, pp. 301-331.

De Carolis, D.M. and Saparito, P. (2006), "Social capital, cognition, and entrepreneurial opportunities: a theoretical framework", Entrepreneurship: Theory and Practice, Vol. 30 No. 1, pp. 41-56.

Delaney, J.T. and Huselid, M.A. (1996), "The impact of human resource management practices on perceptions of organizational performance", Academy of Management Journal, Vol. 39 No. 4, pp. 949-969.

Doms, M., Lewis, E. and Robb, A. (2010), "Local labor force education, new business characteristics, and firm performance", Journal of Urban Economics, Vol. 67 No. 1, pp. 61-77.

Dubina, I.N., Campbell, D.F.J., Carayannis, E.G., Chub, A.A., Grigoroudis, E. and Kozhevina, O.V. (2017), "The balanced development of the spatial innovation and entrepreneurial ecosystem based on principles of the systems compromise: a conceptual framework", Journal of the Knowledge Economy, Vol. 8 No. 2, pp. 438-455.

Envick, B.R. (2005), "Beyond human and social capital: the importance of positive psychological capital for entrepreneurial success", Entrepreneurial Executive, Vol. 10 No. 1, pp. 41-52.

Etzkowitz, H. and Leydesdorff, L. (2000), "The dynamics of innovation: from national systems and "mode 2" to a triple helix of university-industry-government relations", Research Policy, Vol. 29 No. 2, pp. 109-123.

Feld, B. (2012), Startup Communities: Building an Entrepreneurial Ecosystem in Your City, John Wiley \& Sons, New York, NY.

Feldman, M., Francis, J. and Bercovitz, J. (2005), "Creating a cluster while building a firm: entrepreneurs and the formation of industrial clusters", Regional Studies, Vol. 39 No. 1, pp. 129-141.

Gielnik, M.M., Uy, M.A., Funken, R. and Bischoff, K.M. (2017), "Boosting and sustaining passion: a long-term perspective on the effects of entrepreneurship training", Journal of Business Venturing, Vol. 32 No. 3, pp. 334-353.

Gladwell, M. (2008), Outliers: The Story of Success, Hachette Book Group, New York, NY. 
IJEBR

26,5
Global Entrepreneurship Monitor (2017), Global Report: 2016/17, Global Entrepreneurship Research Association, Wellesley, MA.

Granovetter, M.S. (1973), "The strength of weak ties", American Journal of Sociology, Vol. 78 No. 6, pp. $1360-1380$.

Harrison, R.T. and Leitch, C. (2010), "Voodoo institution or entrepreneurial university? Spin-off companies, the entrepreneurial system and regional development in the UK”, Regional Studies, Vol. 44 No. 9, pp. 1241-1262.

Hayes, A.F. (2013), Introduction to Mediation, Moderation, and Conditional Process Analysis: A Regression-based Approach (D.A. Kenny Ed.), The Guilford Press, New York, NY.

Hayward, M.L.A., Forster, W.R., Sarasvathy, S.D. and Fredrickson, B.L. (2010), "Beyond hubris: how highly confident entrepreneurs rebound to venture again", Journal of Business Venturing, Vol. 25 No. 6, pp. 569-578.

Hechavarria, D.M. and Ingram, A. (2014), "A review of the entrepreneurial ecosystem and the entrepreneurial society in the United States: an exploration with the global entrepreneurship monitor dataset", Journal of Business and Entrepreneurship, Vol. 26 No. 1, pp. 1-35.

Hmieleski, K.M. and Carr, J.C. (2008), "The relationship between entrepreneur psychological capital and new venture performance", Frontiers of Entrepreneurship Research, Vol. 28 No. 4, pp. 1-15.

Hmieleski, K.M., Carr, J.C. and Baron, R.A. (2015), "Integrating discovery and creation perspectives of entrepreneurial action: the relative roles of founding CEO human capital, social capital, and psychological capital in contexts of risk versus uncertainty", Strategic Entrepreneurship Journal, Vol. 9 No. 4, pp. 289-312.

Hoang, H. and Antoncic, B. (2003), "Network-based research in entrepreneurship: a critical review", Journal of Business Venturing, Vol. 18 No. 2, pp. 165-187.

Hoang, H. and Yi, A. (2015), "Network-based research in entrepreneurship: a decade in review", Foundations and Trends ${ }^{\circledR}$ in Entrepreneurship, Vol. 11 No. 1, pp. 1-54.

Hobfoll, S.E. (2002), "Social and psychological resources and adaptation", Review of General Psychology, Vol. 6 No. 4, pp. 307-324.

Isenberg, D.J. (2011), The Entrepreneurship Ecosystem Strategy as a New Paradigm for Economic Policy: Principles for Cultivating Entrepreneurship, Institute of International and European Affairs, Dublin, Ireland.

Johanson, J. and Vahlne, J.-E. (2011), "Markets as networks: implications for strategy-making”, Journal of the Academy of Marketing Science, Vol. 39 No. 4, pp. 484-491.

Kibler, E., Kautonen, T. and Fink, M. (2014), "Regional social legitimacy of entrepreneurship: implications for entrepreneurial intention and start-up behaviour", Regional Studies, Vol. 48 No. 6, pp. 995-1015.

Kim, B.-Y. and Kang, Y. (2014), "Social capital and entrepreneurial activity: a pseudo-panel approach", Journal of Economic Behavior and Organization, Vol. 97, pp. 47-60.

King, M.F. and Bruner, G.C. (2000), "Social desirability bias: a neglected aspect of validity testing", Psychology and Marketing, Vol. 17 No. 2, pp. 79-103.

Kline, C., McGehee, N.G., Paterson, S. and Tsao, J. (2013), "Using ecological systems theory and density of acquaintance to explore resident perception of entrepreneurial climate", Journal of Travel Research, Vol. 52 No. 3, pp. 294-309.

Kor, Y.Y., Mahoney, J.T. and Michael, S.C. (2007), "Resources, capabilities and entrepreneurial perceptions", Journal of Management Studies, Vol. 44 No. 7, pp. 1187-1212.

Kshetri, N. (2014), "Developing successful entrepreneurial ecosystems: lessons from a comparison of an Asian tiger and a Baltic tiger", Baltic Journal of Management, Vol. 9 No. 3, pp. 330-356.

Lau, C.M. and Ngo, H.Y. (2004), "The HR system, organizational culture, and product innovation", International Business Review, Vol. 13 No. 6, pp. 685-703. 
Leyden, D.P., Link, A.N. and Siegel, D.S. (2014), "A theoretical analysis of the role of social networks in entrepreneurship”, Research Policy, Vol. 43 No. 7, pp. 1157-1163.

Liguori, E., Bendickson, J., Solomon, S. and McDowell, W.C. (2019), "Development of a multidimensional measure for assessing entrepreneurial ecosystems", Entrepreneurship \& Regional Development, Vol. 31 Nos 1-2, pp. 7-21.

Lin, N. (2002), Social Capital: A Theory of Social Structure and Action, Cambridge University Press, New York, NY.

Liu, C.-H. and Lee, T. (2015), "Promoting entrepreneurial orientation through the accumulation of social capital, and knowledge management", International Journal of Hospitality Management, Vol. 46, pp. 138-150.

Liu, M. (2015), "An ecological review of literature on factors influencing working mothers' child care arrangements", Journal of Child and Family Studies, Vol. 24 No. 1, pp. 161-171.

Lumpkin, G.T. and Dess, G.G. (2001), "Linking two dimensions of entrepreneurial orientation to firm performance: the moderating role of environment and industry life cycle", Journal of Business Venturing, Vol. 16 No. 5, pp. 429-451.

Luthans, F., Luthans, K.W. and Luthans, B.C. (2004), "Positive psychological capital: beyond human and social capital”, Business Horizons, Vol. 47 No. 1, pp. 45-50.

Luthans, F., Avey, J.B., Avolio, B.J., Norman, S.M. and Combs, G.M. (2006), "Psychological capital development: toward a micro-intervention”, Journal of Organizational Behavior, Vol. 27 No. 3, pp. 387-393.

Luthans, F., Youssef, C.M. and Avolio, B.J. (2007), Psychological Capital: Developing the Human Competitive Edge, Oxford University Press, Oxford, UK.

Luthans, F., Avey, J.B. and Patera, J.L. (2008), "Experimental analysis of a web-based training intervention to develop positive psychological capital", The Academy of Management Learning and Education, Vol. 7 No. 2, pp. 209-221.

Luthans, F., Avolio, B.J., Avey, J.B. and Norman, S.M. (2007), "Positive psychological capital: measurement and relationship with performance and satisfaction", Personnel Psychology, Vol. 60 No. 3, pp. 541-572.

Lux, A.A., Grover, S.L. and Teo, S.T.T. (2019), "Reframing commitment in authentic leadership: untangling relationship-outcome processes", Journal of Management \& Organization, pp. 1-19, doi: $10.1017 / \mathrm{jmo} .2019 .78$.

Mack, E. and Mayer, H. (2016), "The evolutionary dynamics of entrepreneurial ecosystems", Urban Studies, Vol. 53 No. 10, pp. 2118-2133.

Mahoney, J.T. and Michael, S.C. (2005), "A subjectivist theory of entrepreneurship", in Alvarez, S.A., Agarwal, R. and Sorenson, O. (Eds), Handbook of Entrepreneurship Research, Springer, New York, NY, pp. 33-54.

Manolova, T.S., Manev, I.M., Carter, N.M. and Gyoshev, B.S. (2006), "Breaking the family and friends' circle: predictors of external financing usage among men and women entrepreneurs in a transitional economy", Venture Capital, Vol. 8 No. 2, pp. 109-132.

Maresch, D., Harms, R., Kailer, N. and Wimmer-Wurm, B. (2016), "The impact of entrepreneurship education on the entrepreneurial intention of students in science and engineering versus business studies university programs", Technological Forecasting and Social Change, Vol. 104, pp. 172-179.

Martin, B.C., McNally, J.J. and Kay, M.J. (2013), "Examining the formation of human capital in entrepreneurship: a meta-analysis of entrepreneurship education outcomes", Journal of Business Venturing, Vol. 28 No. 2, pp. 211-224.

Marvel, M.R., Davis, J.L. and Sproul, C.R. (2016), "Human capital and entrepreneurship research: a critical review and future directions", Entrepreneurship: Theory and Practice, Vol. 40 No. 3, pp. 599-626.
Entrepreneurial ecosystems 
IJEBR 26,5

1038
Mason, C. and Brown, R. (2013), "Creating good public policy to support high-growth firms", Small Business Economics, Vol. 40 No. 2, pp. 211-225.

Matlay, H. (2008), "The impact of entrepreneurship education on entrepreneurial outcomes", Journal of Small Business and Enterprise Development, Vol. 15 No. 2, pp. 382-396.

McPherson, M., Smith-Lovin, L. and Cook, J.M. (2001), "Birds of a feather: homophily in social networks", Annual Review of Sociology, Vol. 27 No. 1, pp. 415-444.

Miao, C., Qian, S. and Ma, D. (2017), "The relationship between entrepreneurial self-efficacy and firm performance: a meta-analysis of main and moderator effects", Journal of Small Business Management, Vol. 55 No. 1, pp. 87-107.

Miller, D. and Le Breton-Miller, I. (2017), "Underdog entrepreneurs: a model of challenge-based entrepreneurship", Entrepreneurship: Theory and Practice, Vol. 41 No. 1, pp. 7-17.

Moore, J.F. (1993), "Predators and prey: a new ecology of competition", Harvard Business Review, Vol. 71 No. 3, pp. $75-83$.

Motoyama, Y. and Knowlton, K. (2017), "Examining the connections within the startup ecosystem: a case study of St. Louis", Entrepreneurship Research Journal, Vol. 7 No. 1, pp. 1-32.

Neal, J.W. and Neal, Z.P. (2013), "Nested or networked? Future directions for ecological systems theory", Social Development, Vol. 22 No. 4, pp. 722-737.

Neck, H.M., Meyer, G.D., Cohen, B. and Corbett, A.C. (2004), “An entrepreneurial system view of new venture creation”, Journal of Small Business Management, Vol. 42 No. 2, pp. 190-208.

Nga, J.K.H. and Shamuganathan, G. (2010), "The influence of personality traits and demographic factors on social entrepreneurship start up intentions", Journal of Business Ethics, Vol. 95 No. 2, pp. 259-282.

Nunnally, J. (1978), Psychometric Theory, 2nd ed., McGraw-Hill, New York, NY.

Obschonka, M. and Silbereisen, R.K. (2012), "Entrepreneurship from a developmental science perspective", International Journal of Developmental Science, Vol. 6 Nos 3-4, pp. 107-115.

Peteraf, M.A. (1993), "The cornerstones of competitive advantage: a resource-based view", Strategic Management Journal, Vol. 14 No. 3, pp. 179-191.

Piperopoulos, P. and Dimov, D. (2015), "Burst bubbles or build steam? Entrepreneurship education, entrepreneurial self-efficacy, and entrepreneurial intentions", Journal of Small Business Management, Vol. 53 No. 4, pp. 970-985.

Pocock, B., Williams, P. and Skinner, N. (2012), "Conceptualizing work, family and community: a socioecological systems model, taking account of power, time, space and life stage”, British Journal of Industrial Relations, Vol. 50 No. 3, pp. 391-411.

Podsakoff, P.M., MacKenzie, S.B., Lee, J.-Y. and Podsakoff, N.P. (2003), "Common method biases in behavioral research: a critical review of the literature and recommended remedies", Journal of Applied Psychology, Vol. 88 No. 5, pp. 879-903.

Poon, J.P., Thai, D.T. and Naybor, D. (2012), "Social capital and female entrepreneurship in rural regions: evidence from Vietnam", Applied Geography, Vol. 35 No. 1, pp. 308-315.

Preacher, K.J. and Hayes, A.F. (2004), "SPSS and SAS procedures for estimating indirect effects in simple mediation models", Behavior Research Methods, Instruments, and Computers, Vol. 36 No. 4, pp. 717-731.

Rauch, A. and Frese, M. (2007), "Let's put the person back into entrepreneurship research: a metaanalysis on the relationship between business owners' personality traits, business creation, and success", European Journal of Work and Organizational Psychology, Vol. 16 No. 4, pp. 353-385.

Rauch, A. and Frese, M. (2012), "Born to be an entrepreneur? Revisiting the personality approach to entrepreneurship", in Baum, J.R., Frese, M. and Baron, R.A. (Eds), The Psychology of Entrepreneurship, Psychology Press, New York, NY, pp. 41-65. 
Reynolds, W.M. (1982), "Development of reliable and valid short forms of the Marlowe-Crowne social desirability scale", Journal of Clinical Psychology, Vol. 38 No. 1, pp. 119-125.

Rideout, E.C. and Gray, D.O. (2013), "Does entrepreneurship education really work? A review and methodological critique of the empirical literature on the effects of university-based entrepreneurship education”, Journal of Small Business Management, Vol. 51 No. 3, pp. 329-351.

Rodrigo-Alarcón, J., García-Villaverde, J., Ruiz-Ortega, M. J. and Parra-Requena, G. (2017), "From social capital to entrepreneurial orientation: the mediating role of dynamic capabilities", European Management Journal, Vol. 36 No. 2, pp. 195-209.

Rosa, E.M. and Tudge, J. (2013), "Urie Bronfenbrenner's theory of human development: its evolution from ecology to bioecology", Journal of Family Theory \& Review, Vol. 5 No. 4, pp. 243-258.

Roundy, P.T. and Fayard, D. (2019), "Dynamic capabilities and entrepreneurial ecosystems: the microfoundations of regional entrepreneurship", Journal of Entrepreneurship, Vol. 28 No. 1, pp. $94-120$.

Saxenian, A. (1994), Regional Advantage: Culture and Competition in Silicon Valley and Route 128, Harvard University Press, Cambridge, MA.

Scheier, M.F. and Carver, C.S. (1985), "Optimism, coping, and health: assessment and implications of generalized outcome expectancies", Health Psychology, Vol. 4 No. 3, pp. 219-247.

Scheier, M.F., Carver, C.S. and Bridges, M.W. (1994), "Distinguishing optimism from neuroticism (and trait anxiety, self-mastery, and self-esteem): a reevaluation of the Life Orientation Test", Journal of Personality and Social Psychology, Vol. 67 No. 6, pp. 1063-1078.

Shane, S. and Venkataraman, S. (2000), "The promise of entrepreneurship as a field of research", Academy of Management Review, Vol. 25 No. 1, pp. 217-226.

Shaw, E., Marlow, S., Lam, W. and Carter, S. (2009), "Gender and entrepreneurial capital: implications for firm performance", International Journal of Gender and Entrepreneurship, Vol. 1 No. 1, pp. 25-41.

Sherer, M., Maddux, J.E., Mercandante, B., Prentice-Dunn, S., Jacobs, B. and Rogers, R.W. (1982), “The self-efficacy scale: construction and validation”, Psychological Reports, Vol. 51 No. 2, pp. 663-671.

Simon, H.A. (1979), "Rational decision making in business organizations", The American Economic Review, Vol. 69 No. 4, pp. 493-513.

Smith, B.W., Dalen, J., Wiggins, K., Tooley, E., Christopher, P. and Bernard, J. (2008), "The brief resilience scale: assessing the ability to bounce back", International Journal of Behavioral Medicine, Vol. 15 No. 3, pp. 194-200.

Smith, C., Smith, J.B. and Shaw, E. (2017), "Embracing digital networks: entrepreneurs' social capital online", Journal of Business Venturing, Vol. 32 No. 1, pp. 18-34.

Snyder, C.R., Harris, C., Anderson, J. R., Holleran, S.A., Irving, L.M., Sigmon, S.T., Yoshinobu, L., Gibb, J., Langelle, C. and Harney, P. (1991), "The will and the ways: development and validation of an individual-differences measure of hope", Journal of Personality and Social Psychology, Vol. 60 No. 4, pp. 570-585.

Spigel, B. (2017), "The relational organization of entrepreneurial ecosystems", Entrepreneurship: Theory and Practice, Vol. 41 No. 1, pp. 49-72.

Spilling, O.R. (1996), "The entrepreneurial system: on entrepreneurship in the context of a megaevent", Journal of Business Research, Vol. 36 No. 1, pp. 91-103.

Stam, W. and Elfring, T. (2008), "Entrepreneurial orientation and new venture performance: the moderating role of intra-and extraindustry social capital", Academy of Management Journal, Vol. 51 No. 1, pp. 97-111.

Stam, W., Arzlanian, S. and Elfring, T. (2014), "Social capital of entrepreneurs and small firm performance: a meta-analysis of contextual and methodological moderators", Journal of Business Venturing, Vol. 29 No. 1, pp. 152-173. 
IJEBR

26,5

1040

Stam, E. (2015), "Entrepreneurial ecosystems and regional policy: a sympathetic critique", European Planning Studies, Vol. 23 No. 9, pp. 1759-1769.

Stephan, U. and Pathak, S. (2016), "Beyond cultural values? Cultural leadership ideals and entrepreneurship", Journal of Business Venturing, Vol. 31 No. 5, pp. 505-523.

Sternberg, R. (2007), "Entrepreneurship, proximity and regional innovation systems", Journal of Economic and Social Geography, Vol. 98 No. 5, pp. 652-666.

Suresh, J. and Ramraj, R. (2012), "Entrepreneurial ecosystem: case study on the influence of environmental factors on entrepreneurial success", European Journal of Business and Management, Vol. 4 No. 16, pp. 95-101.

Sweetland, S.R. (1996), "Human capital theory: foundations of a field of inquiry", Review of Educational Research, Vol. 66 No. 3, pp. 341-359.

Tan, E. (2014), "Human capital theory: a holistic criticism", Review of Educational Research, Vol. 84 No. 3, pp. 411-445.

Teece, D.J., Pisano, G. and Shuen, A. (1997), "Dynamic capabilities and strategic management", Strategic Management Journal, Vol. 18 No. 7, pp. 509-533.

Teo, S.T.T., Pick, D., Xerri, M. and Newton, C. (2016), "Person-organization fit and public service motivation in the context of change", Public Management Review, Vol. 18 No. 5, pp. 740-762.

Tian, Y.A., Nicholson, J.D., Eklinder-Frick, J. and Johanson, M. (2017), "The interplay between social capital and international opportunities: a processual study of international 'take-off' episodes in Chinese SMEs”, Industrial Marketing Management, Vol. 70, pp. 180-192.

Tomaskovic-Devey, D., Leiter, J. and Thompson, S. (1994), "Organizational survey nonresponse", Administrative Science Quarterly, Vol. 39 No. 3, pp. 439-457.

Tudge, J.R.H., Mokrova, I., Hatfield, B.E. and Karnik, R.B. (2009), "Uses and misuses of Bronfenbrenner's bioecological theory of human development", Journal of Family Theory and Review, Vol. 1 No. 4, pp. 198-210.

Uzzi, B. (1997), "Social structure and competition in interfirm networks: the paradox of embeddedness", Administrative Science Quarterly, Vol. 42 No. 1, pp. 35-67.

Valerio, A., Parton, B. and Robb, A. (2014), Entrepreneurship Education and Training Programs Around the World: Dimensions for Success, The World Bank, Washington, DC.

Van de Mortel, T.F. (2008), "Faking it: social desirability response bias in self-report research", Australian Journal of Advanced Nursing, Vol. 25 No. 4, p. 40.

Van de Ven, H. (1993), "The development of an infrastructure for entrepreneurship", Journal of Business Venturing, Vol. 8 No. 3, pp. 211-230.

Venkataraman, S. (1997), "The distinctive domain of entrepreneurship research", Advances in Entrepreneurship, Firm Emergence and Growth, Vol. 3 No. 1, pp. 119-138.

Wagener, S., Gorgievski, M. and Rijsdijk, S. (2010), "Businessman or host? Individual differences between entrepreneurs and small business owners in the hospitality industry", Service Industries Journal, Vol. 30 No. 9, pp. 1513-1527.

Walker, E.A. and Webster, B.J. (2007), "Gender, age and self-employment: some things change, some stay the same", Women in Management Review, Vol. 22 No. 2, pp. 122-135.

Wanous, J.P. and Reichers, A.E. (1996), "Estimating the reliability of a single-item measure", Psychological Reports, Vol. 78 No. 2, pp. 631-634.

World Economic Forum (2013), Entrepreneurial Ecosystems Around the Globe and Company Growth Dynamics, World Economic Forum, Geneva, Switzerland.

Yoon, H., Yun, S., Lee, J. and Phillips, F. (2015), "Entrepreneurship in East Asian regional innovation systems: role of social capital”, Technological Forecasting and Social Change, Vol. 100, pp. 83-95. 
Youndt, M.A., Snell, S.A., Dean Jr, J.W. and Lepak, D.P. (1996), "Human resource management, manufacturing strategy, and firm performance", Academy of Management Journal, Vol. 39 No. 4, pp. 836-866.

Zhao, W., Ritchie, J.R.B. and Echtner, C.M. (2011), "Social capital and tourism entrepreneurship", Annals of Tourism Research, Vol. 38 No. 4, pp. 1570-1593.

Corresponding author

Andrei Alexander Lux can be contacted at: a.lux@ecu.edu.au

For instructions on how to order reprints of this article, please visit our website:

www.emeraldgrouppublishing.com/licensing/reprints.htm

Or contact us for further details: permissions@emeraldinsight.com 